\title{
Long-Term Demographic Trends in Prehistoric Italy: Climate Impacts and Regionalised Socio-Ecological Trajectories
}

\author{
Alessio Palmisano, et al. [full author details at the end of the article]
}

Accepted: 26 August 2021 / Published online: 7 October 2021

(c) The Author(s) 2021

\begin{abstract}
The Italian peninsula offers an excellent case study within which to investigate longterm regional demographic trends and their response to climate fluctuations, especially given its diverse landscapes, latitudinal range and varied elevations. In the past two decades, summed probability distributions of calibrated radiocarbon dates have become an important method for inferring population dynamics in prehistory. Recent advances in this approach also allow for statistical assessment of spatiotemporal patterning in demographic trends. In this paper we reconstruct population change for the whole Italian peninsula from the Late Mesolithic to the Early Iron Age (10,000-2800 cal yr BP). How did population patterns vary across time and space? Were fluctuations in human population related to climate change? In order to answer these questions, we have collated a large list of published radiocarbon dates $(n=4010)$ and use this list firstly to infer the demographic trends for the Italian peninsula as a whole, before addressing each of five sub-regions in turn (northern, central, and southern Italy, Sicily, Sardinia). We also compare population fluctuations with local paleoclimate proxies (cave, lake, marine records). At a pan-regional scale, the results show a general rapid and substantial increase in population in the Early Neolithic with the introduction of farming at around 8000 cal yr BP and further dramatic increases during the Bronze and Iron Age ( 3800-2800 cal yr BP). However, different regional demographic trajectories exist across different regions of Italy, suggesting a variety of localised human responses to climate shifts. Population and climate appear to have been more closely correlated during the early-mid Holocene (Mesolithic-Neolithic), while later in the Holocene (Bronze-Iron Ages) they decouple. Overall, across the Holocene the population dynamics varied by region and depended on the long-term socio-ecological dynamics prevailing in a given area. Finally, we include a brief response to the paper 'Radiocarbon dated trends and central Mediterranean prehistory' by Parkinson et al. (J Word Prehist 34(3), 2021) synchronously published by Journal of World Prehistory but wholly independently developed-indicating how our conclusions accord with or differ from one another.
\end{abstract}

Keywords Italy $\cdot$ Prehistory $\cdot$ Demography $\cdot$ Climate $\cdot$ Radiocarbon summed probability distribution - Landscape ecology 


\section{Introduction}

Over the past couple of decades, there has been renewed interest in the study of past demographic patterns, with a view to understanding how population growth and decline do or do not run in step with cultural change, with increase or decrease in social complexity and/or with environmental change (Bevan et al., 2017; Freeman, et al., 2018; Riede, 2009; Roberts, et al., 2019; Shennan, 2000, 2001; Turchin, et al., 2018; Wigand \& McCallum, 2017). In this context, summed probability distributions (SPDs) of calibrated archaeological radiocarbon dates have become particularly popular for inferring demographic trends in prehistory (Rick, 1987; Shennan \& Edinborough, 2007; Bocquet-Appel et al., 2009; Shennan et al., 2013; Porčić et al., 2016; de Pablo et al., 2019; Palmisano et al., 2019); and for assessing population response to climate shifts (Weninger et al., 2009; Williams et al., 2010; Fiorentino et al., 2013; Capuzzo et al., 2018; Roberts et al., 2018; Riris \& Arroyo-Kalin, 2019). More recently, this approach has benefitted from a series of methodological advances dealing with issues such as the effects of the calibration curve (Weninger et al., 2015; Williams, 2012); taphonomic loss (Surovell et al., 2009); biases in the original archaeological dataset (Brown, 2017; McLaughlin, 2019); and testing statistically spatio-temporal trends in the fluctuations of SPDs of calibrated radiocarbon dates (Timpson et al, 2014; Crema et al., 2016; Crema et al., 2017; Bevan et al., 2017; Edinborough et al., 2017; Palmisano et al., 2017; Ramsey, 2017; McLaughlin, 2019; Robinson et al., 2019).

In this paper, we will use SPDs of calibrated radiocarbon dates to infer population dynamics in prehistoric Italy from the Late Mesolithic to Early Iron Age (10,000-2800 cal yr BP). The Italian peninsula offers an excellent case study for the investigation of long-term regional demographic trends and their response to climate fluctuations, especially given its diverse landscapes, latitudinal range and varied elevations. The prehistoric Italian communities saw substantial local developments occurring at a different pace and magnitude across the mainland and the islands. The most relevant of these was the introduction of farming that occurred earliest in south-east Italy (Apulia) at the end of the ninth millennium BP ( 6200 BC) and gradually spread across the whole peninsula up to north-west Italy (Liguria) and Sardinia by c. 7700 cal yr BP (Skeates, 2002, 2003; Malone, 2003; Robb, 2007; Fiorentino et al., 2013; Silva \& Vander Linden, 2017; Shennan, 2018, pp. 110-114; Starnini et al., 2018; see Table 1 for a chronological scheme). The arrival of farming coupled with improved climate conditions is believed to have brought a rapid and substantial increase in population, with communities permanently residing in houses and villages, supported by a mixed economy of hunting, farming and small-scale herding (Barker, 1975, pp. 144-147; Robb \& van Hove, 2003; Robb, 2007, p. 26; Branch et al., 2014; Spiteri et al. 2017; Pilaar Birch \& Vander Linden, 2018; Gaastra \& Vander Linden, 2018). During the Middle and Late Neolithic, farming strategies became more intensive with greater evidence for the production and consumption of cereals and legumes, of mixed livestock (but a prevalence of cattle), and less evidence than before for hunted red deer and wild boar (Corridi \& Moroni, 1993; Fugazzola Delpino et al., 1993; 


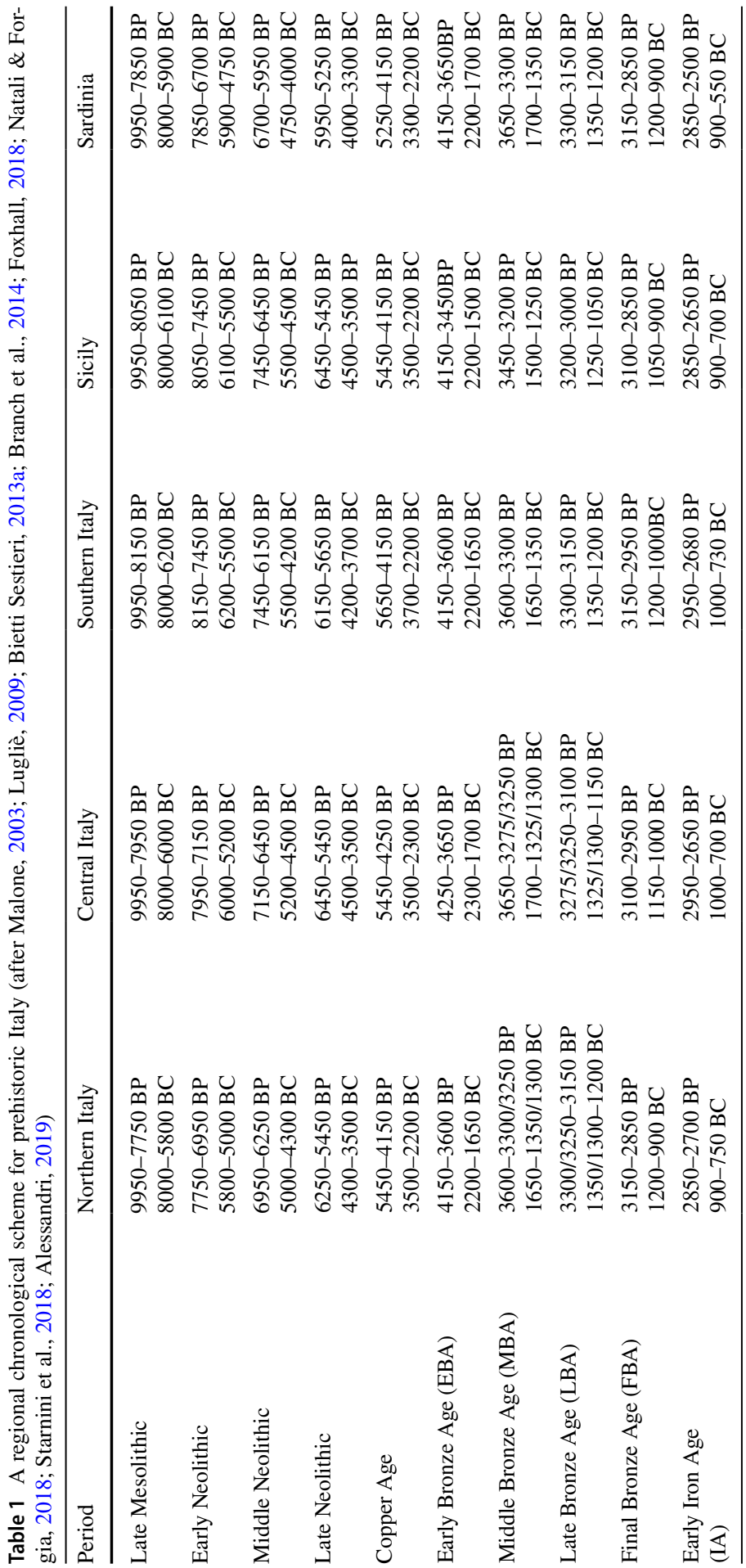


Villari, 1995; Ferrari et al., 2001; Anzidei et al., 2010). The Copper Age saw a further apparent increase in population-with some sites exceeding one hectare in size-and demographic growth appears to have continued during the Bronze Age and peaked (at least in Etruria and Latium) in the Iron Age, with the establishment of large urban centres exceeding 50-100 hectares in size (Gennaro \& Peroni, 1986; Barker \& Stoddart, 1994; Bietti Sestieri, 2013a; Nicolis, 2013; Fulminante, 2014, pp. 44-47; Alessandri, 2015, 2016; Stoddart et al., 2019). Furthermore, major rapid climate changes (e.g. the so-called $8.2 \mathrm{ka}, 4.2 \mathrm{ka}$ and $3.2 \mathrm{ka} \mathrm{cal}$ yr BP events) could have affected demographic trends and triggered different local human responses and cultural changes (cf. Drysdale et al., 2006; Weninger et al., 2006; Roberts et al., 2011). A recent work by Finné et al., (2019, pp. 6-8) shows a drier climate in Italy from 10,000 to $~ 8500$ cal yr BP, and then a gradual trend towards wetter conditions until $7000 \mathrm{BP}$. After that, there is little variability until 4500 cal yr BP when the climate became drier in both the north and the south. Unlike the eastern Mediterranean, experiencing arid conditions $\sim 3000 \mathrm{cal}$ yr BP, the climate in Italy was relatively wet in this period (Finné et al., 2019, p. 13). However, there was significant regional climate variation across the whole Italian peninsula and islands during the last ten millennia.

Given these premises, estimating regional demographic trends over the longue durée provides useful starting points for understanding how variegated were the socio-ecological trajectories across the whole Italian peninsula and islands. Most studies concerning population patterns in prehistoric Italy have used a limited corpus of archaeological evidence and focused on smaller regions within well-defined cultural periods. Here, we include the entirety of the Italian peninsula from north to south and the major islands (Sicily and Sardinia). Chronologically we range from the Late Mesolithic to the Early Iron Age (10,000-2800 cal yr BP). The demographic patterns inferred from SPDs of calibrated radiocarbon dates are compared quantitatively with several paleoclimatic proxies (cave, lake, marine records) collected at different latitudes in order to assess the impact of climate change on human population in different regions (northern, central, and southern Italy, Sicily, and Sardinia).

\section{Geographical Setting and Materials}

\section{The Study Area}

Italy, given its substantial latitudinal extent, exhibits an extraordinary diversity of landscapes and shows a varied topography that, moving from north to south, includes coastlands, plains, and high mountain chains such as the Alps and the Apennines. Mountainous and hilly areas prevail over lowlands, although the Po Valley covers a large part of northern Italy (Marchetti et al., 2017). The altitudinal gradient ranging from the highest peak of Mont Blanc (4810 m above mean sea level) to the lowest point at Le Contane, Jolanda di Savoia (3.4 m below mean sea level) results in marked differences in terms of climate and vegetation composition (Fredi \& Lupia Palmieri, 2017). The main mountain chains influence the climate in the peninsula, given that the Alps protect the Po Plain from the cold winds of central Europe, while 
the Apennines contain the maritime humid air from the Tyrrhenian sea (Fratianni \& Acquaotta, 2017). Average annual rainfall shows a latitudinal gradient with values exceeding $2500 \mathrm{~mm}$ in the Alps and Apennines and as low as $238 \mathrm{~mm}$ at the shores of Capo Carbonara in southern Sardinia (Marchetti et al., 2017). Italy's administrative regional division is the result of the physiography of the landscape. While the Po Valley dominates most of northern Italy, the Apennine range divides the rest of the Italian peninsula longitudinally and represents a physical barrier between the Tyrrhenian and the Adriatic side. Although altitudes are lower in southern Italy, the territory is prevailingly mountainous and hilly, and the most extensive lowland areas are the Plain of Foggia in northern Apulia and the Plain of Sybaris in north-eastern Calabria. Sicily, separated from the Italian mainland by the Strait of Messina, is mostly hilly and is traversed along the northern coast by the mountain chain of Madonie (2000 m above mean sea level), a continuation of the Apennines. The Plain of Catania, to the south of the Mount Etna, is the most extensive plain on the island. Sardinia, in the Tyrrhenian Sea, is mostly hilly and reaches its peak in the large massif of Gennargentu (1834 m above mean sea level), in the central-south of the island. The Ozieri and the Campidano are the largest plains respectively in the north and the south of Sardinia.

In the present study, we have subdivided Italy into five geographical units: northern, central and southern peninsular Italy, Sicily and Sardinia (Fig. 1). The spatial coverage of each sub-region has been defined (1) in order to guarantee a sufficient wealth of radiocarbon dates for producing reliable SPDs, and (2) because of the need to provide a coherent framework both spatially and chronologically for analysing comparatively archaeological data and palaeoclimate records.

\section{Inferring Past Human Demographic Trends from Archaeological Data}

Population estimates build on the assumption that the density of the archaeological evidence found in a given study area is proportional to population (for a good overview of the archaeological proxies that represent good indicators for inferring past population trends see Drennan et al., 2015). In other words, the bigger the population, the stronger the signal in the archaeological record (e.g. the higher the density of pottery sherds, stone tools, site counts, radiocarbon dates.). However, such indicators do not offer good evidence for absolute numbers of people in the past, but rather provide an idea of relative intensities of population and proportional change through time. The most common proxy for inferring past human population dynamics has been raw counts of archaeological sites or estimated settlement sizes derived from landscape survey. However, over the past two decades, SPDs of archaeological radiocarbon dates have begun to be used to model past demographic trends in prehistory, because they have the potential to document trends at higher levels of resolution. This latter approach has had limited impact in Italy with the exception of rare examples focussing on single regions or well-defined cultural periods (Fiorentino et al., 2013; Palmisano et al., 2017; Palmisano et al., 2018; Capuzzo et al., 2018; Stoddart et al., 2019). The 


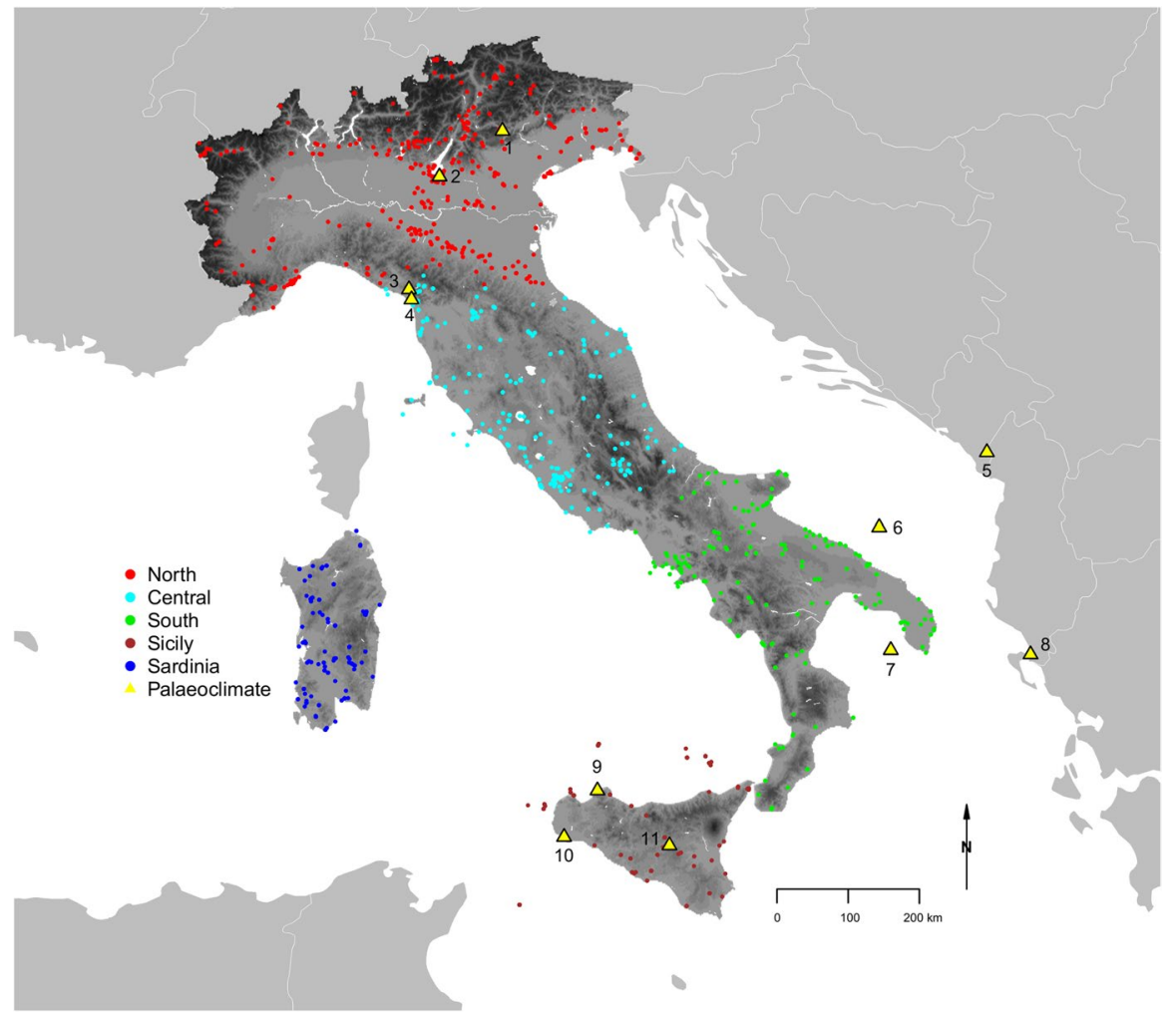

Fig. 1 Map showing the distribution of sites with radiocarbon dates and palaeoclimate records (see Table 2 for references)

reluctance to use radiocarbon dates as a proxy for past human population reflects a broader preference for using archaeological survey data to estimate past settlement intensity (e.g. Bintliff \& Sbonias, 1999).

The SPDs of calibrated radiocarbon dates are effective in Italy only for the period up to $\sim 2800$ cal yr BP because after that time the SPDs massively underestimate a widely agreed and widely evidenced boom in population during the Archaic-Classic and Roman periods (Palmisano et al., 2017; Stoddart et al., 2019). This is because, rather than using radiocarbon samples, most Classical and Roman archaeologists rely on typo-chronological schemes defined by shortlived pottery types and coins for dating archaeological layers. To a lesser extent this also applies to protohistoric archaeologists working in the period between c.3500 and 2700 cal yr BP. In addition, the period affected by the Hallstatt radiocarbon calibration plateau (c.2750-2350 cal yr BP) has discouraged most researchers from collecting radiocarbon samples belonging to Late Iron Age and Archaic-Classical archaeological contexts.

Both archaeological survey and radiocarbon dates are imperfect proxies and are subject to several potential problems. These include biases in research 
focus towards particular periods or regions; variations in the statistical methods adopted and the intensity of the investigation; taphonomic loss; the visibility of diagnostic artefacts; and research budgets (Cherry, 1983; Surovell et al., 2009; Armit et al., 2013; Contreras \& Meadows, 2014; Torfing, 2015a, 2015b; BecerraValdivia et al., 2020). A kernel density map (Fig. 2a) of the spatial distribution of radiocarbon dates shows uneven spatial sampling of radiocarbon dates due to research biases focussing on specific topics (e.g. the introduction of farming, the spread of metallurgy, the rise of early complex societies). This in turn emphasises particular areas and periods, such as the Neolithic 'villaggi trincerati' in Apulia (Cassano \& Manfredini, 1983; Cassano et al., 1987); the Bronze Age Terramare culture in the central Po Valley (Bernabò Brea et al., 1997; Cardarelli, 2010); the Neolithic Impressed Ware Pottery and Chassey cultures in Liguria (Maggi, 1983, 1997; Bagolini \& Biagi, 1990); or the transition between the Late Bronze and Early Iron Age in central Italy (Pacciarelli, 2001; Peroni, 1988). By contrast, the underrepresentation of specific geographical areas and periods is due to either the ephemeral evidence of residential buildings and settlements (for instance the Copper Age across most of the Italian peninsula) or to a lower academic interest (e.g. the Neolithic in the Islands, the Late Neolithic in Basilicata and Calabria). In addition, the regional budget discrepancies (in terms of total GDP) emphasise further the difference in the intensity of radiocarbon dating between the richer regions of northern and central Italy and the rest of the country (see Fig. 2c; $r=0.66, p$-value $<0.01$, Spearman coefficient based on the rank-order correlation between the number of radiocarbon dates and the total GDP of each region).

Although archaeological surveys generally attempt to capture all sites within a landscape, regardless of period, research biases persist. For instance, one major source of archaeological survey data is represented by the Forma Italiae, a largescale series of archaeological maps and gazetteers of sites composed of 46 volumes published between 1926 and 2017 (Castagnoli, 1974; Sommella, 2009). An acknowledged bias of the archaeological survey published under the umbrella of the Forma Italiae is an underestimation of prehistoric sites. Unlike the radiocarbon dates, raw site count and estimated settlement size are more problematic as proxies during the Neolithic because of the need to rely on pottery-based chronologies that are less refined than the ones during the so-called 'metal ages'. Instead, the recent developments in quantitative analysis of SPD of calibrated radiocarbon dates and the new wealth of data augmented by the availability of digital inventories allow the systematic collation of data, the evaluation of genuine patterns assessed statistically, and the reconstruction of population fluctuations based on absolute calendar dates rather than on relative chronological frameworks often defined on broadly dated pottery.

Despite the issue described above, multi-proxy studies have shown broad agreement in the demographic trends produced by the SPD of radiocarbon dates and other archaeological indices (e.g. raw site count, aggregated estimated settlement size) (French, 2015; French \& Collins, 2015; Nielsen et al., 2019; Palmisano et al., 2017; Tallavaara et al., 2010). The 'Changing the Face of the Mediterranean' project has produced a suite of papers from different regions across the Mediterranean basin showing a good correspondence between the trends inferred from archaeological survey data (raw 


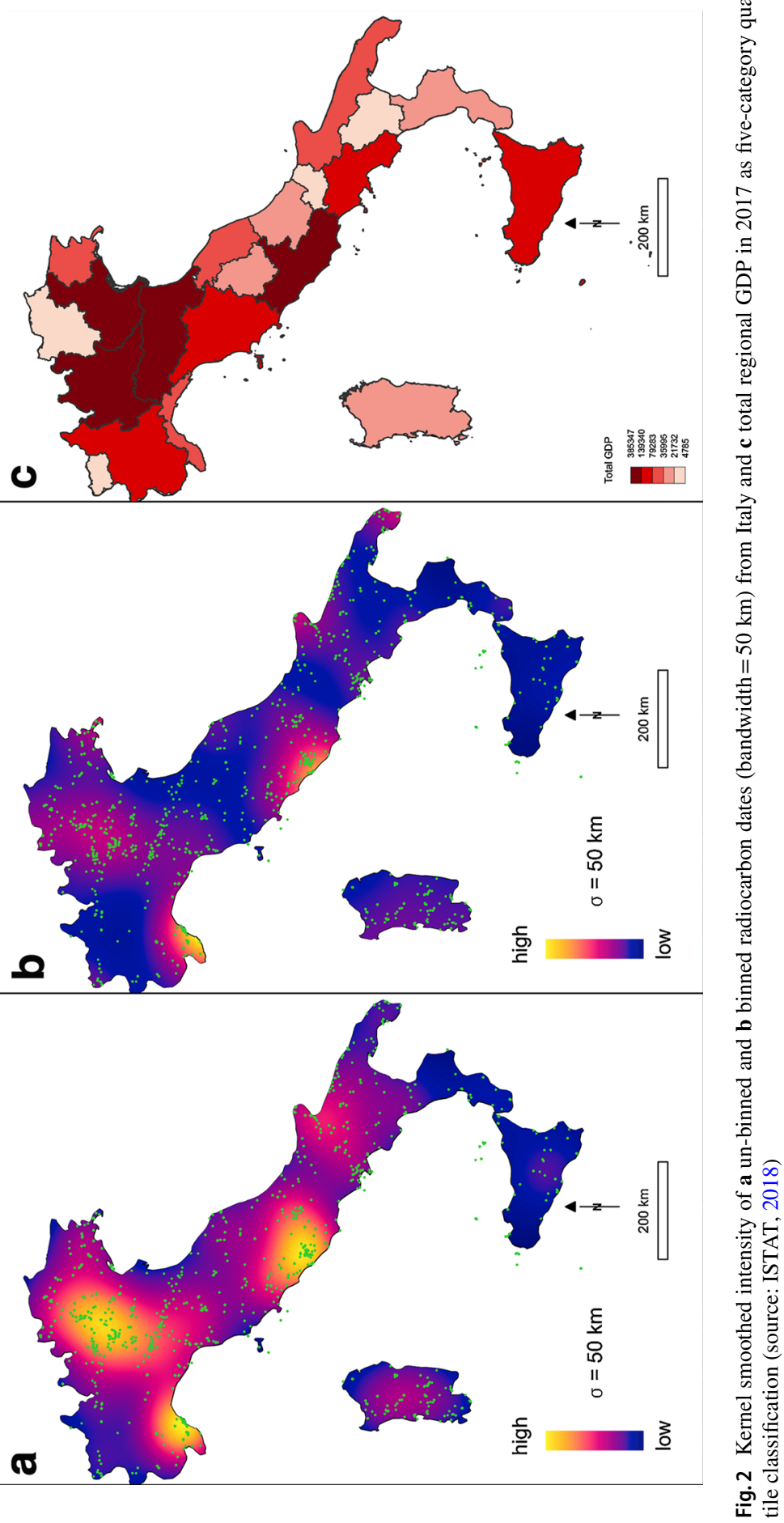


count, settlement size) and SPD of radiocarbon dates, confirming that the latter can be regarded as a robust proxy for modelling past human population (see Bevan et al., 2019; Berger et al., 2019; Palmisano et al., 2019; Roberts et al., 2019; Stoddart et al., 2019; Weiberg et al., 2019). Furthermore, recent works focussing on central Italy and based on a systematic digitisation of landscape survey gazetteers have shown a strong correspondence between time series of settlement data (raw counts, estimated settlement size) and SPDs of radiocarbon over a chronological span from the Late Mesolithic to the Early Iron Age (Palmisano et al., 2017; Stoddart et al., 2019). Further work is therefore needed to bring together archaeological settlement datasets of sufficient size and scale to allow comparison with the SPD record for the whole of Italy. However, in the absence of a full-coverage digital settlement dataset for the entire Italian peninsula, we would argue that the SPDs can represent a reliable sub-sample to use as an empirically derived heuristic device for examining the causal relationships between climate change and population. We are aware of the limits of using just one proxy (radiocarbon dates) for modelling population fluctuations and this will be borne in mind in the interpretations that follow in this paper.

Here we make use of a total of 4010 radiocarbon dates from 947 sites, collected either from online sources and extant databases (e.g. RADON [Hinz et al., 2012]; ORAU date lists [2016]; EUROEVOL [Manning et al., 2016]; EUBAR [Capuzzo et al., 2014]; CALPAL [Weninger, 2018]), or from a wide range of publications such as published reports, journal articles and so on (see Supplemental Material 1 for a full list of sources). We roughly estimate that the overall sample used in this study represents $\sim 70 \%$ of the total existing radiocarbon dates collected in Italy from archaeological contexts, with the remaining dates being either unpublished or stored in hard-copy grey literature that is difficult to retrieve comprehensively. To our knowledge, this is the largest collation of published radiocarbon dates for Italy so far. We checked most of the dates by comparing different sources and then georeferenced them (see Fig. 1). The radiocarbon dates have been collected over a slightly broader time range of 11,000 to 2000 uncal yr BP in order to avoid edge effects. All of these radiocarbon dates are from archaeological contexts, with the majority being samples of bone, charcoal and wood. Radiocarbon dates with poorly understood marine reservoir offsets (all shells) and that do not have anthropogenic causes (e.g. radiocarbon samples collected from environmental cores) have been excluded and are not part of the above total. Fewer than 30 dates have standard errors greater than 300 years. The total number of dates exceeds the suggested minimum threshold of 200-500 to produce reliable SPDs of calibrated radiocarbon dates with reduced statistical fluctuation for a time interval of 10-8000 years (Michczyńska \& Pazdur, 2004; Michczyńska et al., 2007; Williams, 2012, pp. 580-581). As a consequence, our dataset can be considered sufficiently large to overcome many of the potential sampling biases that might affect the patterns.

\section{Palaeoclimate Records}

Finné et al. (2019) demonstrated that there were significant differences in hydroclimatic history between different parts of the Mediterranean basin during the Holocene. Consequently, we have restricted our analysis to a paleoclimate dataset 
from 11 sites in, or immediately adjacent to, Italy at different latitudes and altitudes (Fig. 1, Table 2; see also Finé et al., 2019). They provide past hydro-climate patterns from: (1) $\delta^{18} \mathrm{O}$ and $\delta^{13} \mathrm{C}$ speleothems and lacustrine carbonates; (2) $\delta^{13} \mathrm{C}$ composition of marine planktonic foraminifera; (3) $\mathrm{Ca} / \mathrm{Ti}$ and $\mathrm{Sr} / \mathrm{Ca}$ ratios from marine and lacustrine sediments; (4) lamina thickness of speleothems; and (5) lake-level fluctuations from sediments. Sites for inclusion had a minimum mean sampling interval of 200 years and a time duration of at least 2000 years. Pollen-based climate reconstructions have not been included because of human impact on vegetation and land cover in Italy, not only during historical times (Stoddart et al., 2019) but also in later prehistory (e.g. Sadori et al., 2004). These paleoclimate records are located mainly in the north or the south of the Italian peninsula, with few in central Italy, and no records at all from Sardinia. Their distribution therefore provides a picture of subregional climatic changes that is spatially congruent with four of the five regions used for archaeo-demographic reconstruction.

Some authors have suggested that the $\delta^{18} \mathrm{O}$ of speleothem calcite represents the precipitation amount during the winter recharge period and, therefore, higher (lower) values indicate drier (wetter) seasonal conditions during winter rather than average annual conditions (Wassenburg et al., 2016; Deininger et al., 2017; Bini et al., 2019). Nevertheless, a unifying satisfactory explanation for $\delta^{18} \mathrm{O}$ values of speleothem calcite in the Mediterranean basin is still debated (Moreno et al., 2014). Instead, the $\delta^{18} \mathrm{O}$ values of lacustrine carbonate are believed to be related with hydro-climate conditions during summer (Leng \& Marshall, 2004; Bini et al., 2019), although more complex explanations have been proposed (Zielhofer et al., 2019).

High lamina thickness speleothems are associated with a positive North Atlantic Oscillation (NAO+) signalling warmer and wetter winter climate conditions, while a negative North Atlantic Oscillation (NAO-) indicates colder and drier winters. Higher $\mathrm{Ca}$ /Ti ratios are linked to $\mathrm{NAO}-$ and indicate colder and drier winters, while lower $\mathrm{Ca} / \mathrm{Ti}$ are associated with warmer and wetter winters and $\mathrm{NAO}+$. Higher $\mathrm{Sr} /$ $\mathrm{Ca}$ ratios are associated with increased sea and lake water salinity and drier climatic conditions, while lower $\mathrm{Sr} / \mathrm{Ca}$ ratios indicate a decreased salinity and a wetter climate.

However, given that each proxy depends on its original local context, the interpretation of the hydro-climatic conditions from the selected palaeoclimate records is rarely straightforward and does not necessarily reflect just wet or dry climate. It is not the main goal of this paper to describe in detail the uncertainties of each proxy (readers are invited to refer to the original publications for a detailed description of each record-see Table 2), but in the final discussion we will bear in mind these issues when comparing the inferred demographic fluctuations with the hydro-climatic trends.

\section{SPD of Calibrated Radiocarbon Dates}

The radiocarbon dates were calibrated and modelled using version 1.4.2 of the $\mathrm{R}$ package rcarbon (Bevan \& Crema, 2021; Crema \& Bevan, 2021). All analyses and figures in this paper are reproducible thanks to the dissemination of the 


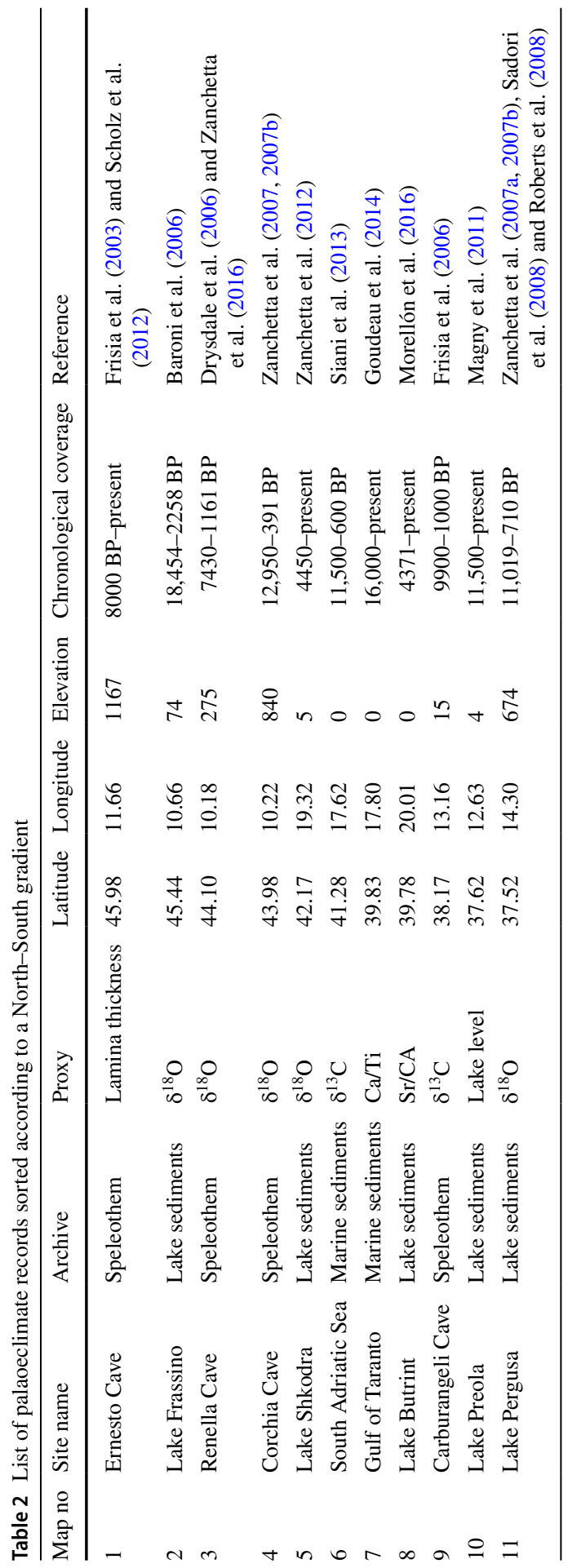


dataset and one script written in R statistical computing language (see Appendix A). We calibrated and summed radiocarbon probability distribution of individual dates over a slightly broader time range from 11,000 to 2000 uncal yr BP in order to avoid edge effects. We reduced the oversampling of specific chronological sitephases (e.g. because of biases in research targets) by aggregating uncalibrated radiocarbon dates from the same site that are within 50 years of each other and dividing by the number of dates that fall in this bin (Timpson et al., 2014). This approach mitigates both the spatial and chronological inhomogeneity of radiocarbon dates available for the whole of Italy (cf. Fig. 2b). Dates having a gap of at least 50 years from the previous one are assigned to a new bin. It is important to note that specific cut-off values may affect substantially the resulting SPDs of calibrated radiocarbon dates. We explored via sensitivity analysis several cut-off values and a visual assessment of the resulting shapes of the SPDs shows little difference between them with values ranging from 50 to 200 . Hence, the probability distributions of 4010 calibrated radiocarbon dates from 947 sites have been aggregated into 2585 (50-year) site bins. Then, the probability distributions of all site bins are summed for the whole Italian peninsula and the five sub-regions (northern, central and southern peninsular Italy, Sicily and Sardinia). However, this procedure may underestimate the real population, being based on a conservative approach that the density of radiocarbon dates from certain site-phases is due to the research interests or resources of the excavator rather than the larger size of the site in that chronological phase.

Following previous work (Weninger et al., 2015) demonstrating that normalised calibrated dates emphasise narrow artificial peaks in SPDs by steepening portions of the radiocarbon calibration curve (throughout we have used IntCal13, Reimer et al., 2013), we opted to sum unnormalised distributions (see former applications in Bevan et al., 2017; Palmisano et al., 2017; Roberts et al., 2018; Riris, 2018).

In order to test if the inferred demographic trends describe meaningful patterns not derived by mere chance, we tested the observed SPDs of calibrated radiocarbon dates against a theoretical null model of demographic change (e.g. uniform, exponential, logistic). We fitted both a logistic and an exponential growth model to the observed SPD, and then back-calibrated random samples (equal to the number of bins) drawn from the fitted model (Bevan \& Crema, 2018: modelTest, 'uncalsample'; for the original approach and slightly different implementations see Shennan et al., 2013; Timpson et al., 2014). The resulting radiocarbon dates were calibrated and their probability distributions summed in order to generate an expected SPD of the fitted model. This process was repeated 1000 times to produce a $95 \%$ confidence envelope. Deviations above and below the $95 \%$ confidence limits of the envelope, respectively, indicate periods of population growth (in red) and decline (in blue) greater than expected according to a logistic or exponential model of population growth. In a logistic model, a population's per capita growth rate gets smaller and smaller as population size approaches a maximum imposed by the carrying capacity of the environment, suggesting that there should be an upper limit to pre-Iron Age population growth. By contrast, the exponential model has the advantage of mimicking taphonomic site loss through time against which the observed SPDs may be compared. Neither logistic nor exponential models offer realistic descriptions of 
real-life population growth, but they are useful as elementary null models for quantitatively assessing population fluctuations through time (Turchin, 2001).

Following the method outlined in Crema et al. (2016) we used a permutation test in order to assess to what degree population fluctuations in each sub-region (northern, central and southern Italy, Sicily and Sardinia) depart from the pan-regional trend (Bevan \& Crema, 2018: permTest). This technique shuffles the labels identifying the region each bin comes from and generates 1000 SPDs from which a $95 \%$ critical grey envelope is derived. Deviations above and below the $95 \%$ confidence limits indicate respectively periods in which the population increase and decrease of each sub-region are greater and lower than the trend for Italy as a whole.

An alternative approach to summed probability modelling is generating bootstrapped composite kernel density estimations (cKDE; for a detailed explanation of the method see Bronk Ramsey, 2017; Brown, 2017; McLaughlin, 2019, pp. 482-485). First, time-bins are randomly sampled with replacement, then a calendar date is randomly drawn from the probability density of each calibrated radiocarbon bin and a Gaussian kernel density is estimated using a 200 -year bandwidth. We repeated these two steps 1000 times in order to produce a $95 \%$ confidence envelope of cKDE. If the confidence interval is narrow, it is very likely that the observed pattern depicts a good picture of reality. This approach has the advantage of smoothing the calibration noise of SPDs of calibrated radiocarbon dates and modelling the uncertainty due the biases of the original input data (e.g. oversampling of specific chronological phases within the same archaeological site).

\section{Results}

\section{Demographic Trends}

SPDs of 4010 normalised (Fig. 3a) and unnormalised (Fig. 3b) calibrated radiocarbon dates have been generated for a period ranging from 10,000 to $2800 \mathrm{cal}$ yr BP . Despite our stated preference for summing calibrated unnormalised dates (Fig. 3b), which avoids artificial spiky peaks in the resulting SPD (Fig. 3a), the two curves do not differ substantially and describe very similar demographic trends as demonstrated by high correlation values $(\mathrm{r}=0.93, p$-value $<0.01$, Pearson). Given that most of the dates come from wood charcoal and the resulting SPD could be subject to an old wood effect, we produced an SPD of unnormalised calibrated dates from short-lived radiocarbon samples (e.g. bones, collagen, grains, twigs). The SPDs with all radiocarbon dates (Fig. 3b) and with only shortlived dates (Fig. 3b, in green) are highly correlated $(\mathrm{r}=0.92, p$-value $<0.01$, Pearson) and we conclude that there is not a significant old wood effect in the resulting post-calibration probability densities. We further assessed the reliability of the generated SPDs by comparing bootstrapped cKDE time series of normalised (Fig. 3a) and unnormalised (Fig. 3b) calibrated radiocarbon dates versus their corresponding SPDs. The two approaches depict very similar trends (Fig. 3a-b) and we can state that biases in the sampling procedure of the original archaeological dataset seem to not have affected the resulting SPDs. The SPDs of 


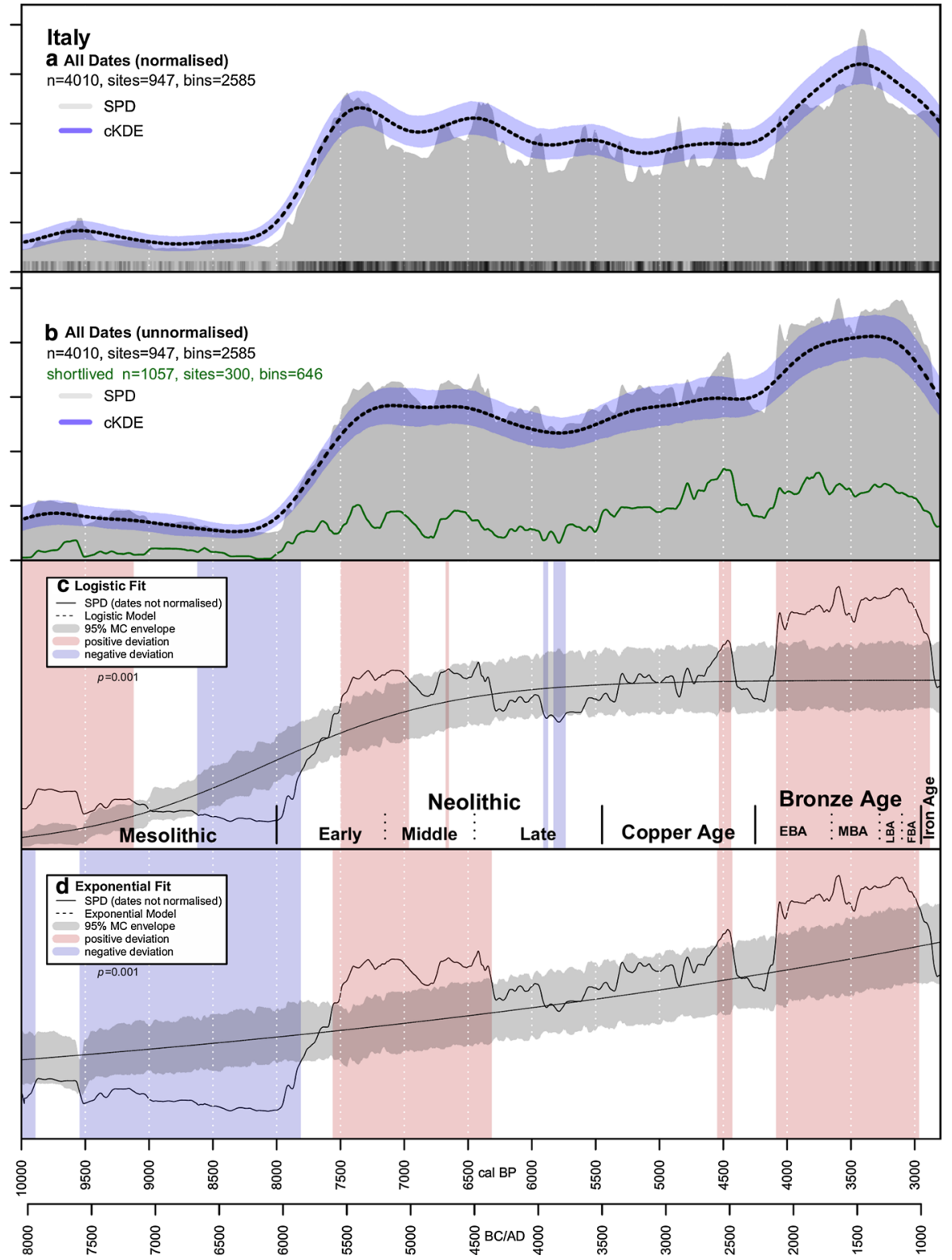

Fig. 3 Summed Probability Distribution (SPD) of a normalised and b unnormalised calibrated radiocarbon dates; c unnormalised (solid line) vs. a fitted logistic; d exponential null model (95\% confidence grey envelope). Blue and red vertical bands indicate respectively chronological ranges within the observed SPD which deviate negatively and positively from the null model. The bar-code-like strip a represents the median values of multiple calibrated radiocarbon bins. Bootstrapped composite Kernel Density Estimation (cKDE) of $\mathbf{a}$ normalised and $\mathbf{b}$ unnormalised calibrated radiocarbon dates (Color figure online) 
unnormalised calibrated radiocarbon dates are then compared against a $95 \%$ confidence envelope for a logistic (Fig. 3c) and an exponential (Fig. 3d) null model. Deviations above (in red) and below (in blue) represent, respectively, patterns of population growth and decline beyond that expected under a long-term logistic or exponential trend. The observed SPDs (black solid line) show similar, but not coinciding, significant deviations from the fitted null models (Fig. 3c-d). In addition, a logistic null model is preferable to other possible null models (e.g. uniform, exponential) given the observed shape of SPD of calibrated radiocarbon dates (Fig. 3c). Significant population growth occurs during the Early Neolithic ( 7600-7000 cal yr BP ) and population decreases in the Late Neolithic between 5900 and 5700 cal yr BP . A further increase of population, although not statistically significant, is indicated during the Copper Age ( 5300-4500 cal yr BP ), which is followed by a decline between 4600 and 4400 cal yr BP. Finally, the prehistoric population reaches its peak during the Bronze and Early Iron Ages, between 4100 and 2900 cal yr BP.

Figure 4 shows how the regional bootstrapped cKDEs and SPDs have similar trends. As mentioned above, the bootstrap technique has the advantage of providing $95 \%$ confidence envelopes of 1000 samples, where each sample draws the same number of bins as the original observed dataset, but duplicates the result of some observations, while others are omitted. This would mitigate, for each region, research biases due to the oversampling of specific periods. However, we would like to point out that given the few radiocarbon dates available for Sicily and Sardinia (Fig. 4d-e) the inferred demographic patterns are to be interpreted cautiously for those two regions. Figure 5 shows the regionally subdivided SPDs of unnormalised radiocarbon dates compared against the all-Italy trend (grey envelope) described above via a permutation test. Such a technique also deals with the issues represented by the size of the samples, as the resulting grey envelopes of the pan-regional trend are larger in those sub-regions with fewer radiocarbon dates, reflecting greater uncertainty (see Fig. 5d-e). All five sub-regions show significant departures from the pan-regional trend over the long-term ( $p$-value $<0.01)$. In northern Italy (Fig. 5a), the population density is significantly above the pan-regional pattern during the Late Mesolithic ( 9300-9000 cal yr BP ) and the Middle/Late Neolithic ( 7000-6000 cal yr BP ), while a substantial decline occurs in the Late/Final Bronze Age ( 3200-2800 cal yr BP ). Central Italy (Fig. 5b) shows several negative local deviations during the Late Mesolithic, Neolithic and Bronze Age, while population grows noticeably in the Copper Age ( 5500-4800 cal yr BP ) and above all in the Final Bronze and Early Iron Age ( 3100-2850 cal yr BP ). Southern Italy (Fig. 5c) shows several negative deviations from the global pattern between the Late Neolithic and the Copper Age and in the Late Bronze and Early Iron Age ( 3200-2800 cal yr BP ), while population peaks in the Early Neolithic $(\sim 8000-7200$ cal yr BP $)$ and in the Bronze Age ( 3700-3500 cal yr BP ). In Sicily and Sardinia, the population trends are generally flat and positive deviations from the pan-regional trend occur in the Bronze Age (Fig. 5d-e).

Pairwise Pearson correlations between all regional SPDs have been calculated in order to assess how demographic patterns differed among the regions in specific sub-periods, viz.: 


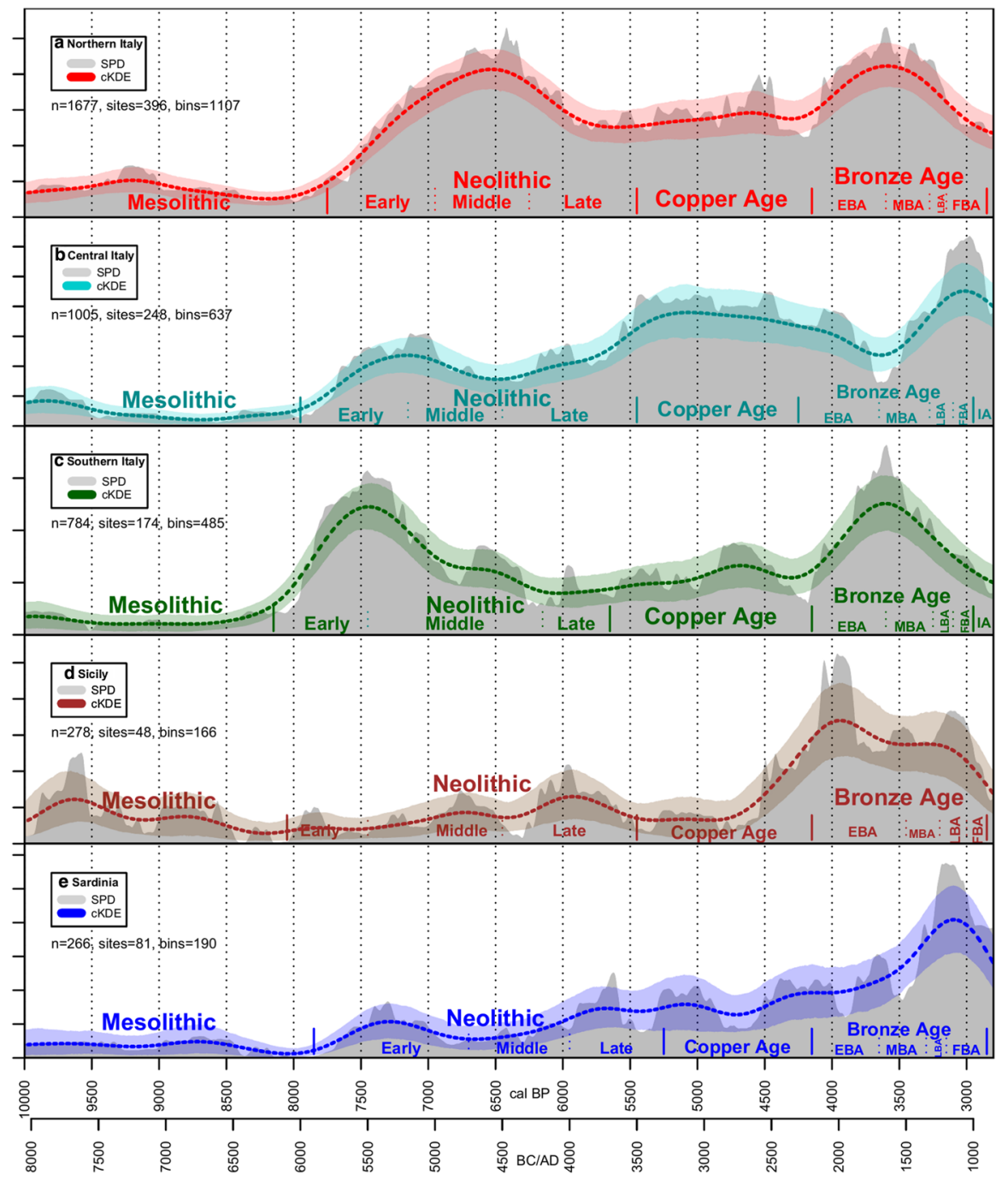

Fig. 4 Bootstrapped composite Kernel Density Estimation (cKDE) for a northern Italy; b central Italy; c southern Italy; d Sicily; and e Sardinia

1. Mesolithic to Early Neolithic (10,000-7000 cal yr BP, Table 3);

2. Early Neolithic to the end of the Copper Age (7000-4200 cal yr BP, Table 4);

3. Bronze and Early Iron Ages (4200-2800 cal yr BP , Table 5).

The results show similar demographic trends in the Italian peninsula prior to $\sim 7000$ cal yr BP, with the exception of Sicily (Table 3); increased regionalisation and contrasting patterns between mainland and islands from the Middle 


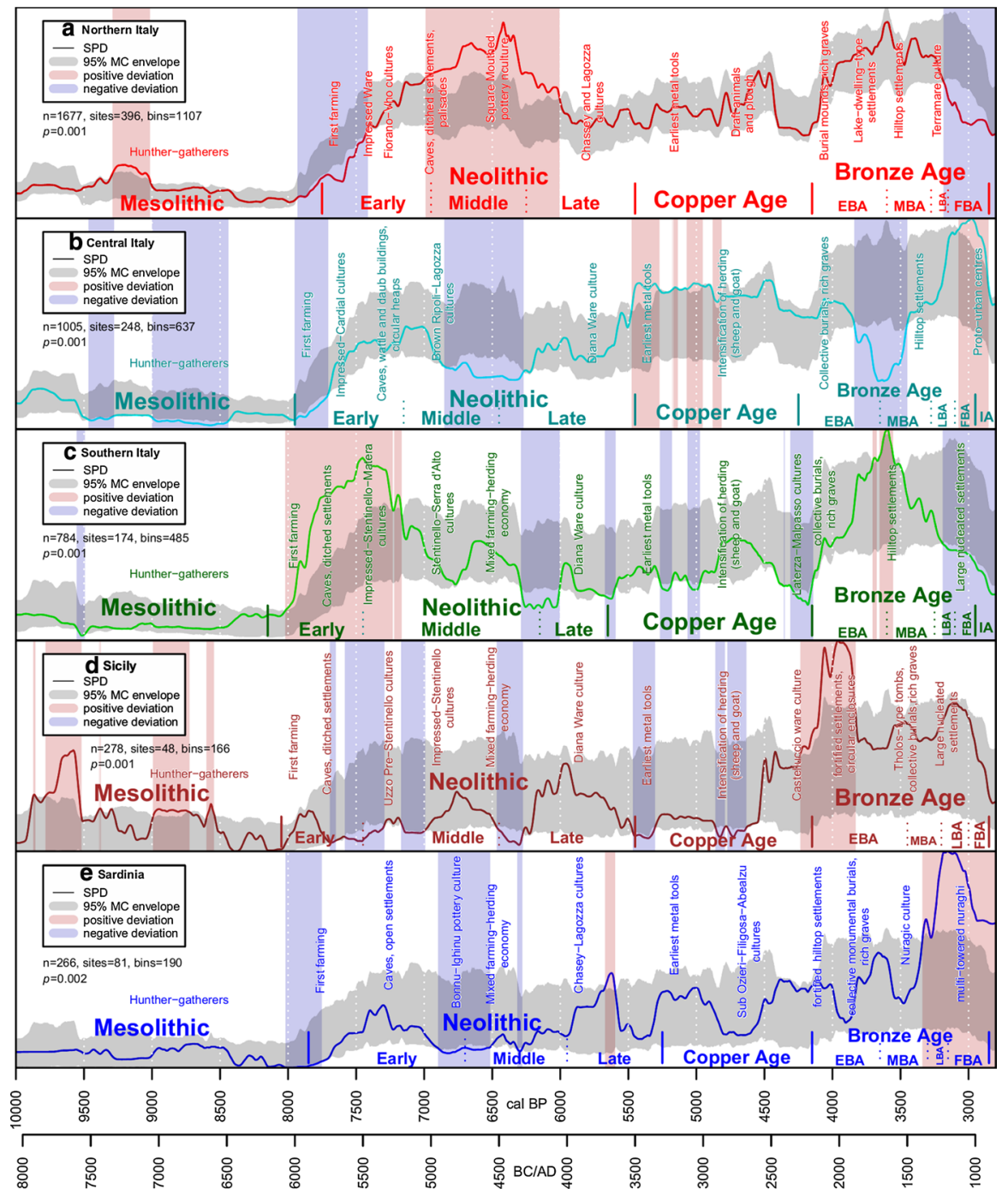

Fig. 5 Regional summed probability distributions (SPDs) of calibrated radiocarbon dates for a northern Italy; b central Italy; c southern Italy; d Sicily; and e Sardinia, compared with a $95 \%$ Monte Carlo envelope of the pan-regional model produced via permutation of sub-regional dates

Table 3 Pearson correlation coefficient r-value matrix for the period 10,000-7000 cal yr BP

\begin{tabular}{llllll}
\hline & North Italy & Central Italy & South Italy & Sicily & Sardinia \\
\hline North Italy & 1 & & & & \\
Central Italy & $\mathbf{0 . 8 7 * *}$ & 1 & & & \\
South Italy & $\mathbf{0 . 6 4} \mathbf{.}^{* *}$ & $\mathbf{0 . 8 2} \mathbf{2}^{* *}$ & 1 & & \\
Sicily & -0.13 & -0.13 & -0.28 & 1 & \\
Sardinia & $\mathbf{0 . 8 0 * *}$ & $\mathbf{0 . 8 0}^{* *}$ & $\mathbf{0 . 6 3}^{* *}$ & 0.003 & 1 \\
\hline
\end{tabular}

Significant correlations are indicated by bold numbers. ${ }^{*} p<0.05, * * p<0.01$ 
Table 4 Pearson Correlation Coefficient r-value matrix for the period 7000-4200 cal yr BP

\begin{tabular}{llllll}
\hline & North Italy & Central Italy & South Italy & Sicily & Sardinia \\
\hline North Italy & 1 & & & & \\
Central Italy & $\mathbf{- 0 . 6 0 * *}$ & 1 & & & \\
South Italy & $\mathbf{0 . 3 8 * *}$ & 0.13 & 1 & 1 & 1 \\
Sicily & $\mathbf{- 0 . 2 8 * *}$ & -0.04 & $\mathbf{- 0 . 3 9 * *}$ & $\mathbf{0 . 4 3} * *$ & 1 \\
Sardinia & $\mathbf{- 0 . 6 9 * *}$ & $\mathbf{0 . 5 1} * *$ & $\mathbf{0 . 4 3} * *$ & & \\
\hline
\end{tabular}

Significant correlations are indicated by bold numbers. ${ }^{*} p<0.05,{ }^{*} p<0.01$

Table 5 Pearson correlation coefficient r-value matrix for the period 4200-2800 cal yr BP

\begin{tabular}{llllll}
\hline & North Italy & Central Italy & South Italy & Sicily & Sardinia \\
\hline North Italy & 1 & & & & \\
Central Italy & $-\mathbf{0 . 7 2 * *}$ & 1 & & & \\
South Italy & $\mathbf{0 . 9 0}^{* *}$ & $-\mathbf{0 . 7 3} * *$ & 1 & 1 & \\
Sicily & 0.17 & 0.11 & -0.03 & -0.31 & 1 \\
Sardinia & $-\mathbf{0 . 4 6}^{* *}$ & $\mathbf{0 . 6 8}^{* *}$ & $-\mathbf{0 . 3 4} * *$ & -0.01 & \\
\hline
\end{tabular}

Significant correlations are indicated by bold numbers. ${ }^{*} p<0.05, * * p<0.01$

Neolithic to the end of the Copper Age (Table 4); and marked interregional differences from the onset of the Bronze Age (Table 5).

\section{Climate Evidence}

Palaeoclimate records suggest that in the Early Holocene the climate of the Italian peninsula was drier and then switched toward wetter conditions after $\sim 8500$ cal yr BP (Fig. 6; see also Finné et al., 2019, p.13). At a majority of sites, the climate was wetter during the mid Holocene than in late Holocene times. The opposite pattern is displayed in two marine records from southeast Italy (sites 6 and 7), and was also inferred from reconstructed water levels in Lago di Accesa in Tuscany (Magny et al., 2007a, 2007b). In contrast to Magny et al. (2015), who envisaged a clear north-south see-saw in Italy's climate during the Holocene, the evidence shown in Fig. 6 does not indicate geographically-coherent differences in sub-regional hydroclimate patterns. The $8.2 \mathrm{ka} \mathrm{BP}$ event is visible in the sediments from Lake Frassino in northern Italy (Baroni et al., 2006, p. 834), while the record from Carburangeli Cave, in Sicily, shows little evidence of significant arid conditions at this time (Frisia et al., 2006, p. 397). Regional climate variations are also visible in the Italian peninsula during the Middle and Late Holocene. Especially in northern Italy (Fig. 6: 1-2), from $8000 \mathrm{cal}$ yr BP there were wetter and more stable conditions until 4500 cal yr $\mathrm{BP}$, punctuated by several drier and warmer episodes, as shown by the records from Ernesto Cave and Lake Frassino (Baroni, 2006, p. 234; Scholz et al., 2012, p. 1378). After $4500 \mathrm{cal}$ yr BP, the hydro-climate trends are less stable and characterised by more pronounced sub-centennial fluctuations between wet and dry episodes. 


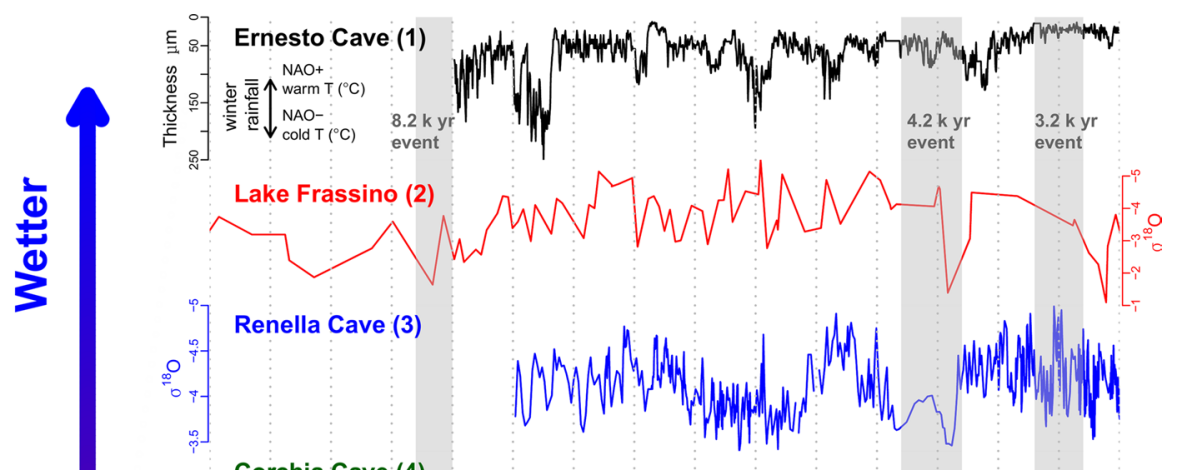

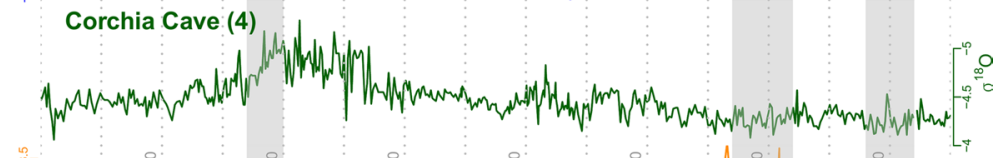

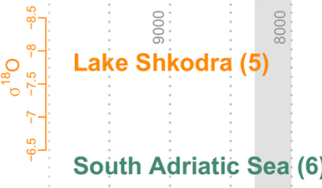

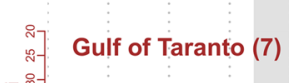

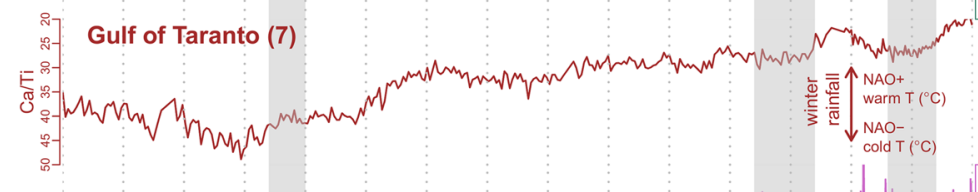

Lake Butrint (8)

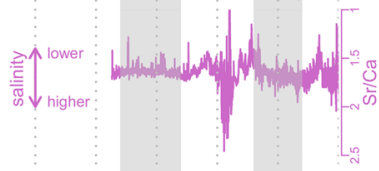

Carburangeli Cave (9)
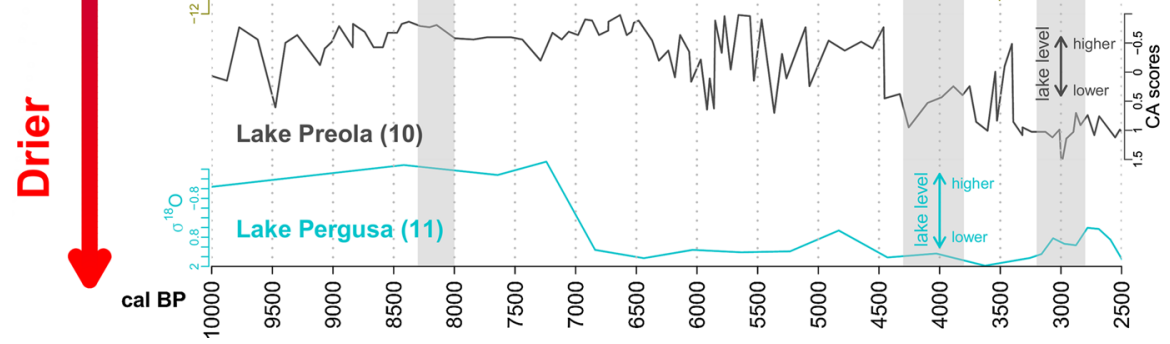

Fig. 6 Selected palaeoclimate proxies from Italy. The grey vertical bands indicate the 8.2, 4.2 and $3.2 \mathrm{k}$ cal yr BP events 
In central Italy (Fig. 6: 3-4), there was a climate trend characterised by gradually drier conditions from 7500 until $2500 \mathrm{cal}$ yr BP, as shown by the $\delta^{18} \mathrm{O}$ speleothem from Corchia cave (Zanchetta et al., 2007a, 2007b, pp. 284-285). In contrast, in Renella Cave we have alternating climate conditions with wetter trends during the timespans 7000-6000 cal yr BP and 5000-4500 cal yr BP, punctuated by drier periods during the spans 6000-5000 and 4500-3800 cal yr BP, and larger alternating episodes of wetter and dry events during the span 3200-2500 cal yr BP. (Drysdale et al., 2006; Zanchetta et al., 2016, pp. 9-10). As noted above, in southern Italy the record from the Gulf of Taranto shows a climate trend characterised by gradual wetter and warmer conditions from 7500 to $2500 \mathrm{cal}$ yr BP, interrupted by slight drier and colder episodes during the spans 4300-3800 and 3200-2800 cal yr BP (Goudeau et al., 2014, pp. 97-99). The south-eastern Adriatic records (Fig. 6: 5-6, 8) show large fluctuations, suggesting unstable climate/hydrological conditions from 4500 to 2500 cal yr BP. In particular, drier conditions occur between $\sim 4200-3900$ cal yr BP and 3500-3200 cal yr BP (Fig. 6: 5-6; Zanchetta et al., 2012, p. 785; Siani et al., 2013, pp. 506-507). In Sicily (Fig. 6: 9-11), the climate/hydrological conditions become drier from 7500 to 2500 cal yr BP. While the records from Lake Preola show a gradual drier trend with large lake-level (climatic) fluctuations during the span 6500-4500 cal yr BP and then an abrupt fall in lake level at 4500 cal yr BP (Magny et al., 2011, pp. 2464-2469), the palaeoclimiate proxies from Carburangeli Cave and Lake Pergusa indicate a rapid and substantial switch to severe and persistent dry conditions from around 7000 to 2500 cal yr BP (Frisia et al., 2006, pp. 397-398; Sadori \& Giardini, 2007; Sadori et al., 2008, p. 12). The 4.2 cal. k yr. BP event is apparent in most of the records included in this study (with the exception of the Gulf of Taranto and Lake Butrint) and seems to indicate one or more drying phases across the whole Italian peninsula, from north to south, during the time period 4300-3800 cal yr BP (Magny et al., 2009; Zanchetta et al., 2016, pp. 9-12; Bini et al., 2019; Isola et al., 2019, pp. 143-146). Unlike the rest of the eastern Mediterranean, which experienced the driest time of the Holocene during the $3.2 \mathrm{cal} . \mathrm{k}$ yr. BP event, Italy seems to have experienced less dry conditions (Finné et al., 2019, p. 13). However, several proxies from northern (Lake Frassino) and southern Italy (Gulf of Taranto, Lake Butrint, Carburangeli Cave, Lake Preola) show a clear drier trend (Fig. 6: 2, 7-10). In contrast, the palaeoclimate proxies from Lake Shkodra, south Adriatic Sea and Lake Pergusa show an overall slight wetter trend, although characterised by pronounced decadal-centennial variability (Fig. 6: 5-6,11).

\section{Comparing Demographic and Climatic Trends}

The demographic proxies (the SPDs of calibrated radiocarbon dates) and the palaeoclimate records with a finer resolution have been binned into 50-year time slices. The use of a 50-year time window can be justified by the fact that the minimum mean sampling interval is at least 50 years (Fig. 6: 1, 3-5, 7-9). Those palaeoclimate records with a coarser chronological resolution and with dates more than 50 years apart have been binned into 200-year (Fig. 6: 6, 10), 400-year (Fig. 6: 2) 
and 600-year (Fig. 6: 11) time slices. As a consequence, the demographic proxies were binned into coarser time slices than these palaeoclimate records.

Pairwise Pearson correlations between SPDs of calibrated radiocarbon dates and the palaeoclimate proxies of each region (northern, central and southern Italy, Sicily) have been calculated for the period from 10,000 to 2800 cal yr BP when possible. However, the time-span under consideration changes according to the chronological coverage provided by each palaeoclimate record. Unfortunately, we could not compare the demographic and climatic trends in Sardinia given the lack of palaeoclimate proxies. In northern Italy (Fig. 7), the population fluctuations are weakly correlated with the palaeoclimatic record from Ernesto Cave $(\mathrm{r}=0.24, p$-value $=0.03)$, while strongly correlated with the climatic trends inferred from Frassino Lake $(r=0.72, p$-value $<0.001)$. In central Italy (Fig. 8), the population shows no correlation with the climatic trends from Renella cave $(\mathrm{r}=-0.04, p$-value $=0.65)$ and is negatively correlated with the hydro-climatic patterns from Corchia cave $(\mathrm{r}=-0.51, p$-value $<0.001)$. In southern Italy (Fig. 9), the SPD of radiocarbon dates shows no correlation with climatic trends
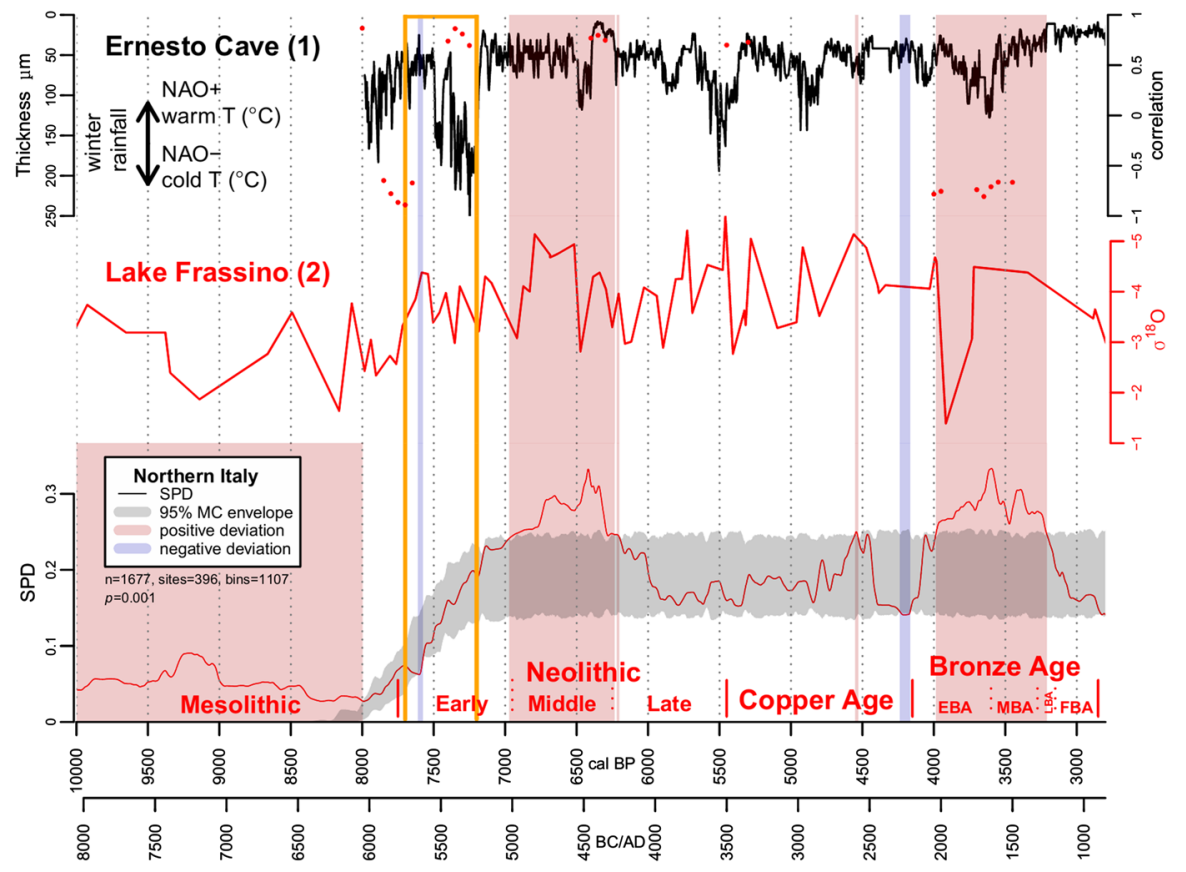

Fig. 7 SPD of unnormalised calibrated radiocarbon dates for northern Italy vs. a logistic null model (95\% confidence grey envelope) compared with palaeoclimate records from Ernesto cave and Lake Frassino. Blue and red vertical bands indicate respectively chronological ranges within the observed SPD which deviate negatively and positively from the null model. The red dots represent significant ( $p$-value $<0.05)$ positive or negative Pearson correlations $(\mathrm{r})$ values ranging from +1 to -1 by using a 500-year moving window. The orange rectangle represents an example of 500-year moving window

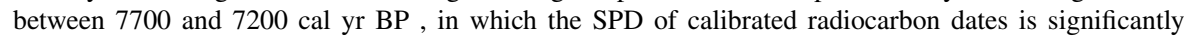
negatively correlated with the climatic trends from Ernesto cave (Color figure online) 


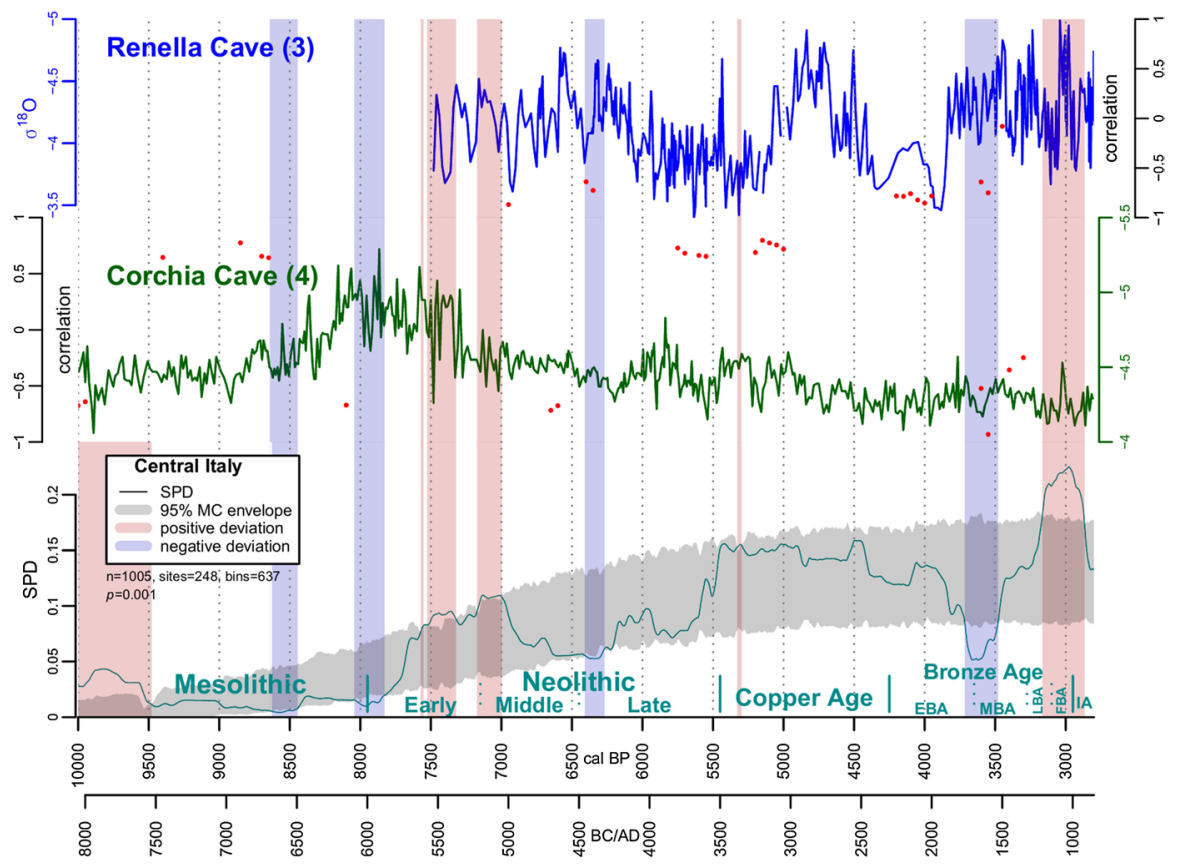

Fig. 8 SPD of unnormalised calibrated radiocarbon dates for central Italy vs. a logistic null model (95\% confidence grey envelope) compared with palaeoclimate records from the caves of Renella and Corchia. Blue and red vertical bands indicate respectively chronological ranges within the observed SPD deviates negatively and positively from the null model. The red dots represent significant $(p$-value $<0.05)$ positive or negative Pearsoncorrelation (r) values ranging from +1 to -1 by using a 500 -year-time moving window (Color figure online)

from the south Adriatic Sea $(\mathrm{r}=0.09, p$-value $=0.73)$ and Lake Butrint $(\mathrm{r}=0.16$, $p$-value $=0.36$, while it shows negative and positive correlations with paleoclimatic records respectively from Shkodra Lake $(\mathrm{r}=-0.39, p$-value $=0.02)$ and the Gulf of Taranto $(r=0.51, p$-value $<0.001)$. In Sicily (Fig. 10), the population trends are negatively correlated with the climatic trends from Carburangeli Cave $(\mathrm{r}=-0.68, p$-value $<0.001)$, Lake Preola $(\mathrm{r}=-0.71, p$-value $<0.001)$ and Lake Pergusa $(\mathrm{r}=-0.65, p$-value $=0.04)$.

However, the results described above only provide us with an overall picture of long-term trends, by treating the time-span under investigation as a whole. Instead, in order to better understand the impact of climate on demographic trends, we have adopted a moving-window approach. The advantage of this approach is to identify periods of correspondence and divergence between human population size and palaeoclimate records over shorter time periods from the early to the late Holocene $(10,000-2800$ cal yr BP ). Thus, for those palaeoclimate records with a finer chronological resolution (Figs. 7: 1; 8: 3-4; 9: 5, 7-8; 10: 9) a 500-year moving-window Pearson correlation has been used, with ten 50-year bins in each time window. In northern Italy (Fig. 7: 1), the population is 


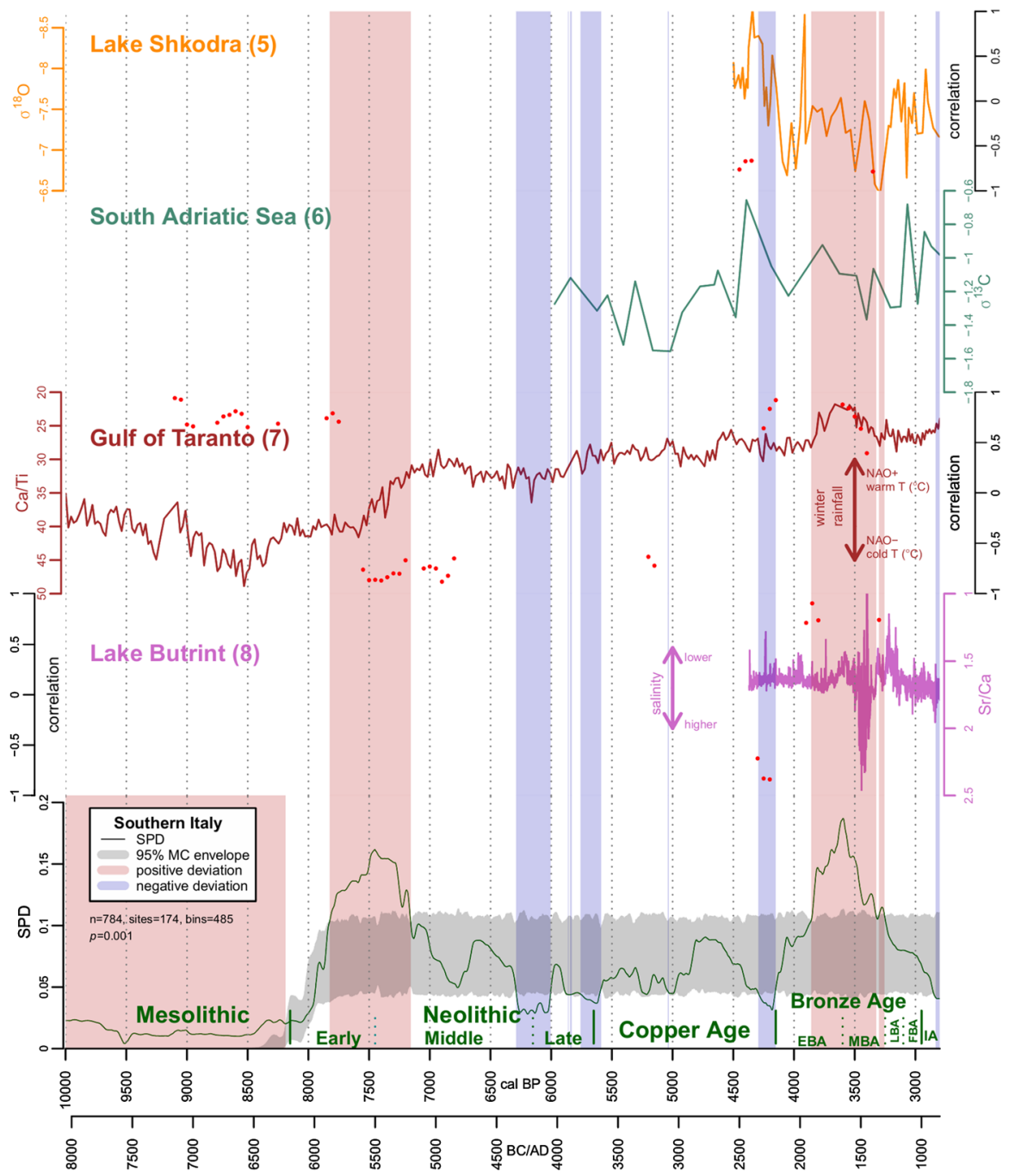

Fig. 9 SPD of unnormalised calibrated radiocarbon dates for southern Italy vs. a logistic null model (95\% confidence grey envelope) compared with palaeoclimate records from the Lakes Shkodra and Butrint, the South Adriatic Sea, and the Gulf of Taranto. Blue and red vertical bands indicate respectively chronological ranges within the observed SPD that deviate negatively and positively from the null model. The red dots represent significant $(p$-value $<0.05)$ positive or negative Pearson correlation $(r)$ values ranging from +1 to -1 by using a 500-year moving window (Color figure online)

negatively correlated with the palaeoclimate record from Ernesto Cave during the transition between the Mesolithic and Early Neolithic ( $p$-value $<0.05$ ), while the records are positively correlated during the Middle Neolithic and the early Copper Age. The most prolonged significant period of negative correlations between demographic and climatic trends occurs during the Bronze Age ( 4000-3000 cal yr BP ), when the population strongly increases despite a shift to a drier climate. 


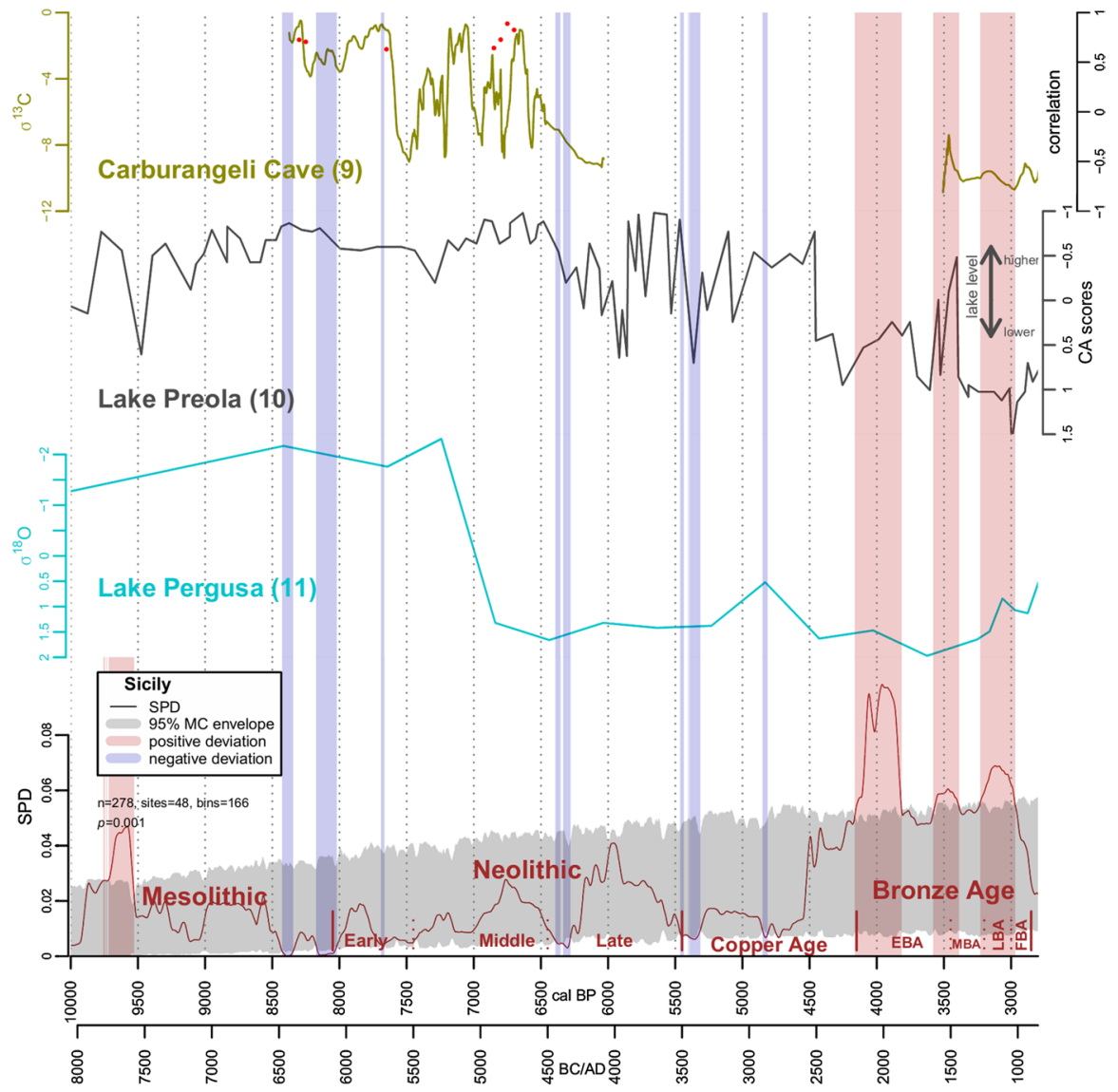

Fig. 10 SPD of unnormalised calibrated radiocarbon dates for Sicily vs. a logistic null model (95\% confidence grey envelope) compared with palaeoclimate records from Carburangeli cave and lakes Preola and Pergusa. Blue and red vertical bands indicate respectively chronological ranges within the observed SPD that deviate negatively and positively from the null model. The red dots represent significant ( $p$-value $<0.05$ ) positive or negative Pearson correlation (r) values ranging from +1 to -1 using a 500year moving window (Color figure online)

In central Italy (Fig. 8), demographic and climatic trends are generally negatively correlated, with the exception of periods of positive significant correlations during the Mesolithic (Fig. 8: 4) and Late Neolithic/Copper Age ( 5800-5000 cal yr $\mathrm{BP}$ ). As for northern Italy, the demographic and palaeoclimate records are negatively correlated during the Bronze Age (Fig. 8: 3-4). In southern Italy (Fig. 9), the population is positively correlated with the palaeoclimate record from the Gulf of Taranto during the Mesolithic/Early Neolithic (Fig. 9: 7; 9200-7200 cal yr BP ) and Bronze Age, while a negative correlation occurs during the Middle and Late Neolithic ( 7200-6300 cal yr BP ). During the Bronze Age, demographic trends are correlated positively with the palaeoclimate record from Lake Butrint (Fig. 9: 8) and negatively with the one from Lake Shkodra (Fig. 9: 5). In 
Sicily, given the coarser resolution of the palaeoclimate records, we adopted a moving-window approach only for Carburangeli Cave, which shows some positive correlations between population and climate during the Late Mesolithic/ Early Neolithic and Middle/Late Neolithic (Fig. 10: 9). During the Copper Age and Bronze Age ( 4500-3000 cal yr BP ), population strongly increased despite a strong shift towards drier climatic conditions (Fig. 10: 9-11).

\section{Discussion}

The results presented in this paper provide a general picture of long-term regional demographic trends in Italy by aggregating the probability distributions of calibrated radiocarbon dates, and highlight the potential impact of climate change on human population. In the following discussion, we examine more comprehensively where and when causal linkages between the population proxies and the palaeoclimate records occurred and describe how the socio-ecological trajectories varied across the Italian peninsula and islands from the Early to the Late Holocene.

\section{Late Mesolithic and the Neolithic Transition}

Profound environmental changes in Italy marked the beginning of the Holocene (c.11,700 cal yr BP ): an overall thermally stable period characterised by higher average temperatures and wetter climatic conditions, the growth of forests, the retreat of permanent snowlines, sea level rise and the flooding of plains due to the deglaciation of ice sheets or glaciers (Antonioli et al., 2002; Giraudi et al., 2011; Magny et al., 2007a, 2007b, 2013; Roberts et al., 2001). Human populations adapted to these changes by developing several subsistence strategies such as hunting, gathering, and fishing characterised by mobility in step with the seasonal availability of resources (Barker, 1999, p. 8; Lo Vetro \& Martini, 2016, pp. 282-286). Systematic archaeological surveys have revealed that Mesolithic communities colonised the whole landscape by settling in caves and rock shelters located in the plains and along the coasts and in seasonal short-visit hunting camps located between 500 and $2000 \mathrm{~m}$ above sea level in the Alps and the Apennines (Broglio, 1992; Lanzinger, 1996; Biagi, 2003, p.142). The faunal assemblages of Mesolithic sites in northern Italy show a diversified system of subsistence relying on food sources such as red deer, wild pig, ducks, wild cat, birds, trout and ibex and chamois at high altitudes (Biagi et al., 1994; Lowe et al., 1994). In central and southern Italy, Castelnovian sites have revealed the exploitation of a wide range of both terrestrial and faunal resources, birds and land snails (Lo Vetro \& Martini, 2016, p. 283; Natali \& Forgia, 2018). The rapid rise in sea level triggered an intense, seasonal consumption of marine resources (fish and shellfish) as a complement to terrestrial sources (e.g. Grotta dell'Uzzo, Grotta d'Oriente, Grotta del Cavallo; Mannino et al., 2007, 2012; Colonese et al., 2014; Lo Vetro \& Martini, 2016, p. 284). In this context, despite ameliorated climatic conditions with the onset of the Early Holocene, human 
population density across the whole Italian peninsula and islands was relatively low during the Late Mesolithic (Figs. 3, 4, 5).

The palaeoclimate records from Lake Frassino, Corchia Cave and the Gulf of Taranto suggest drier climatic conditions between 10,000 and 8500 cal yr BP (Fig. 6: $2,4,7)$ compared to today, and appear in contrast with higher lake levels at Pergusa and Preola in Sicily (Fig. 6: 10-11). Apart from regional discrepancies in hydroclimatic conditions in Italy during the Early Holocene, some scholars have proposed that the so-called $8.2 \mathrm{k}$ cal yr BP cooling event could have hindered the spread of farming beyond the Aegean zone until wetter climatic conditions occurred (Krauss et al., 2014; Weninger et al., 2006). Although this hypothesis seems to be corroborated by a rapid increase of population in Italy from 8000 cal yr BP (Figs. 2, 3), a precise causal link between climate and the introduction of farming in the Italian peninsula needs to be further investigated and could be the result of the interplay of different factors (climatic, social, demographic, economic: Robb \& Miracle, 2007; Whittle \& Cummings, 2007; Vander Linden, 2011). In addition, the available palaeoclimate records show that Italy experienced gradually wetter climatic conditions from $8.5 \mathrm{k}$ cal yr BP to $7.0 \mathrm{k}$ cal yr BP and the so-called $8.2 \mathrm{k}$ cal yr BP event could have had only a minor impact (Fig. 6: 2, 4, 7, 9-11; Finné et al., 2019, pp. 6-8).

The introduction of farming from western Greece and the Balkans to Italy and northwards is visible from the dramatic increase of population shown by the SPD of calibrated radiocarbon dates after $\sim 8000$ cal yr BP (Figs. 2, 3; Bagolini, 1980; Pessina \& Rottoli, 1996; Pilaar Birch \& Vander Linden, 2018; Silva \& Vander Linden, 2017). Southeast Italy was neolithicised several centuries before the rest of Italy, around the end of the ninth millennium BC, as indicated by the permutation test showing a dramatic increase of population greater than that in the rest of the whole of Italy between 8000 and 7200 cal yr BP (Fig. 5c; Alexander, 2005; Skeates, 2003), though the relative magnitude of the population in southern Italy could have been augmented by research biases focussing on particular zones of Puglia and Campania. The earliest Neolithic occupation in Italy is particularly evident in the Tavoliere plain of Apulia, characterised by a large number of Early Impressed Ware ditched settlements (around 1000) ranging from small sites (less than one hectare) to medium-sized sites (1-4 ha) and very large sites (>20 ha) such as Passo di Corvo and Tavernola (Tinè, 1983; Malone, 2003, 253; Whitehouse, 2014). The farming practices appear to have spread rapidly and patchily across the rest of the Italian peninsula and islands at a pace faster than the rate proposed by the 'wave of advance model' (Ammermann \& Cavalli-Sforza, 1984). Thus, Italy experienced a full neolithicisation process by $7700 \mathrm{cal} \mathrm{yr}$ BP , when the travelling front of an incoming population reached Liguria and the Po Plain in northern Italy (see Fig. 7; Pessina \& Tinè, 2008, pp. 39-41; Branch et al., 2014; Starnini et al., 2018). Radical changes in settlement patterns characterised the transition to the Neolithic, with more sedentary farming communities preferring to settle in open-air sites located at altitudes below $500 \mathrm{~m}$ above sea level (Biagi, 2003, pp. 142-145). The Apennine chain did not represent a barrier to settlement and internal intermontane valleys in Tuscany were occupied by villages with wattle and daub structures surrounded by drystone walls (Calvi Rezia, 1980; Grifoni Cremonesi, 1992), while in Lazio the first farmers occupied marshy 
areas by founding hamlets on terraces and colluvial deposits and lake-dwellings on wooden posts (Anzidei, 1987; Fugazzola Delpino et al., 1993). In this context, similar regional demographic trends occurred in the Italian peninsula and Sardinia from the Late Mesolithic to the Early Neolithic (Table 3). Climatic trends in northern (Lake Frassino and Ernesto Cave) and southern (Gulf of Taranto) Italy seem to match the population patterns: the first half of the eighth millennium BP was characterised by wetter climatic conditions and by an increase of the population (see Figs. 7 \& 9; cf. Fiorentino et al., 2013; Pearce, 2013). By contrast, in central Italy population dramatically increased despite a gradual trend towards drier climatic conditions in the Early Neolithic (Fig. 8), while the population density in Sicily does not appear to have increased despite a relatively wet climate (Fig. 10). In Sicily and Sardinia the Neolithic transition could be related to the fact that the first farming communities reached islands well after mainland areas (Malone, 2003, p. 255). However, the absence of a rapid and striking population growth in the resulting SPDs (Fig. 5d, e) may also be due to the scantness of the radiocarbon samples available (Fig. 5d, e). In Sardinia, the cultural break between the Mesolithic and the Neolithic cultures (in terms of settlement layout, lithic industry, the introduction of obsidian) supports the hypothesis of a demic spread of farming and the exploitation of most ecological niches of the island by new communities (Tanda, 1995; Fenu et al.1999; Martini et al., 2007). Given that only 6 out of 74 known Early Neolithic sites have been excavated stratigraphically (Lugliè, 2009), the demographic trend inferred from the SPDs of radiocarbon dates is likely to be an underestimation of the real population. Similarly, in Sicily the population levels inferred from the SPDs seems to be an underestimation of the real scenario, given the thriving of the ditched Stentinello villages that sprang up in eastern Sicily, which reached a size up to 2-3 hectares (e.g. Stentinello, Megara Hyblaea; Giannitrapani, 2017; Pessina \& Tinè, 2008).

An increase of arboreal percentage (AP \%) all over the country, indicating often densely forested landscapes, is evident at the onset of the Holocene and is probably related to an increase of temperature and precipitation after the Younger Dryas (Magri et al., 2015, p. 269). Although the AP percentage increased rapidly during the Early Holocene, the tree cover shows regional differences with AP $>90 \%$ in the Alps and the northern Apennines of the peninsula and around $70 \%$ in the plains of central and southern Italy (Magri et al., 2015, Fig. 3). Environmental data from Liguria show that the introduction of farming and the increase of population resulted in woodland clearance for grazing land and cultivation (Branch et al., 2014, p. 207). Pollen data from central Italy (Tuscany and Lazio) seem to indicate human-induced deforestation since the Early Neolithic, from around 7500 cal yr BP (Colombaroli et al., 2008, Colombaroli et al., 2009; Stoddart et al., 2019). The pollen data from Lake Pergusa in Sicily show a gradual decrease in the AP \% from 8000 onwards (Sadori \& Narcisi, 2001). Despite a dramatic increase of population during the Early Holocene, it seems that the human impact on the landscape during the first half of the eighth millennium BP was not so dominant, since the AP percentage was over $70 \%$ in most parts of Italy independently of a North-South gradient (Magri et al., 2015, 282; Starnini et al., 2018, 302). 


\section{From Neolithic to Copper Age}

The arrival of farming in Italy brought a rapid and substantial increase in population (Fig. 3), with communities permanently residing in houses and villages, supported by a mixed economy of hunting, farming and small-scale herding (Barker et al., 1987; Salque et al., 2012). The Early and Middle Neolithic communities settled mainly in nucleated villages located in lowlands, while in the Late Neolithic most people lived in dispersed settlements and rarely in sites of any great size (Robb, 2007, pp. 261-264). During the Middle and Late Neolithic, farming strategies became more intensive, with greater evidence for the production and consumption of cereals and legumes, of mixed livestock (but a prevalence of sheep/goat), and less evidence than before for hunted red deer and wild boar (Fugazzola Delpino et al., 1993; Anzidei \& Zarattini, 2007, p. 89). Although the Italian peninsula experienced a radical and almost synchronous shift in population density with the onset of farming 8000 cal yr. BP (Fig. 3), the observed SPDs show more differentiated regional patterns during the Middle and Later Neolithic (Fig. 5 and Table 4). Topography could have affected settlement patterns and the dispersed sites may be the result of an ecological adaptation in a highly rugged and mountainous landscape. However, the variation in settlement patterns cannot be explained by geography alone, as some dispersed sites were located in the lowlands of Puglia and Materano during the Diana period (Lo Porto, 1989; Tinè, 1983). Instead, a combination of factors such as geography, regional cultural traditions, and subsistence and defensive strategies could explain the variation in the location and intra-site spatial arrangement of Neolithic settlements. In particular, in northern Italy the population peaked during the Middle Neolithic — as testified by some very large sites belonging to the Fiorano culture in Emilia Romagna and Vhò culture in the central Po Valley (e.g. Riolo Terme, Savignano, Luogo di Romagna; Von Eles Masi \& Steffè, 1987; Bernabò Brea \& Steffè, 1990)—and decreased during the Late Neolithic (Fig. 5a). In central Italy, the advent of farming resulted in a smaller increase of population than in the rest of mainland Italy and the sites tended to be smaller in size and to exploit ecological zones along perennial rivers and lakes (Fig. 5b; Skeates, 1994; Bellini et al., 2008, 2009; Radi \& Pannocchia, 2018). Instead, the population in southern Italy rocketed during the Early Neolithic and started declining from $7200 \mathrm{cal}$ yr BP onwards until the end of the Late Neolithic (Fig. 5c; cf. Fiorentino et al., 2013). However, the apparent decline of population during the Late Neolithic may also be augmented by the fact that most of the archaeological investigation in southern Italy, and especially in Puglia, focused on the Early Neolithic, prioritising the introduction of farming in the research agenda. In contrast, in Sicily and Sardinia the most marked increase in population density started only in the Late Neolithic (Fig. 5d, e) with the expansion in size of villages on the slopes and the surrounding plain of Mount Etna (Malone \& Stoddart, 2000) and the fairly large settlements of round stone huts belonging to the Late Neolithic Otzieri culture (Atzeni, 1987; Giannitrapani, 2017). However, this picture could be biased by the patchiness and scantness of the original datasets from these two regions.

During the transition from the Late Neolithic to the Copper Age, the population seems not to have increased substantially despite an enhanced agricultural 
production favoured by the introduction of technological innovations such as metallurgy, wheeled vehicles and the plough (Fig. 3; Arcà, 2004; Robb, 2007, pp. 287-288). This period was characterised by the abandonment of sizeable nucleated Neolithic villages, which were progressively replaced by dispersed short-lived settlements, seasonal campsites and caves, which left ephemeral archaeological evidence (Fugazzola Delpino et al., 2003; Manfredini et al., 2005; Dolfini, 2019). Therefore, a decrease in population during this period could be related to the reduced visibility of the archaeological record rather than to a genuine demographic pattern. However, it seems that in central Italy population was boosted significantly during the Copper Age (Fig. 5b), a picture also corroborated by archaeological surveys carried out in the area showing an increase of sites during the Late Neolithic/Copper Age transition in Tyrrhenian and Adriatic central Italy (Manfredini et al., 2009). During this time period, only three pairs of correlations between demographic patterns in different regions show statistically-significant and positive ' $r$ ' values. Moreover, none of them involves geographically adjacent regions, highlighting how demographic trends had become regionally specific by the later Neolithic and Copper Age (Tables 3, 4).

During the Middle Holocene, different regional climatic trends and human responses are visible in the Italian peninsula. In northern Italy, the two significant peaks of the population during the Middle Holocene ( 6800-6650; 6500-6200 cal yr BP ) seem to be positively correlated with the palaeoclimate records from Ernesto Cave and Lake Frassino (Fig. 7). Even the very short-term declines of the population during the Late Neolithic/Copper Age transition seem to be correlated positively with the climatic trends (Fig. 7). In central Italy, despite gradually drier conditions from $7500 \mathrm{cal}$ yr BP, populations increased and boomed during the Copper Age (Fig. 8). In this perspective, the demise of nucleated villages and the switch to seasonal settlements and to a more intense pastoralism could be interpreted as a response of the central Italian communities to a drier climatic regime (Barker, 1981, p. 158; Dolfini, 2019). The only positive correlation with local climate records is detectable during the time-span 6800-6000 cal yr BP, when the population trends are correlated with the hydro-climate patterns from Corchia Cave and seem to suggest a decline of population due to a long-lasting drying phase (Fig. 8). However, when compared to the pan-Italian climate z-scores, Roberts et al. (2019, Fig. 5c) found a positive correlation between demographic trends in west central Italy and hydro-climate between 6000 and $3500 \mathrm{cal} \mathrm{yr} \mathrm{BP.} \mathrm{In} \mathrm{southern} \mathrm{Italy,} \mathrm{it} \mathrm{is} \mathrm{more} \mathrm{prob-}$ lematic to assess the relationship between population and climate because only the palaeoclimatic record from the Gulf of Taranto provides a long-term picture. The population of southern Italy seems to be negatively correlated when compared with the hydro-climate records from the Gulf of Taranto (Fig. 9) and its decline could be ascribed to an exacerbated soil exhaustion and salinity rather than climate alone (Whitehouse, 2014, p. 74). However, the $4.2 \mathrm{k}$ cal. yr BP event, which is commonly visible in paleoclimatic proxies, seems to have triggered a significant decline in population (Fig. 9). In Sicily, an apparently abrupt shift towards persistent dry conditions from $7000 \mathrm{cal}$ yr BP could have hindered an increase of population that was low until the beginning of the Bronze Age (Fig. 10). Such a low population density corresponds with the raw counts of sites from some archaeological surveys in the 
inner part of Sicily (Giannitrapani, 2017, pp. 53-54). In addition, several communities of the island still relied mostly on husbandry and pastoral activities and a full Neolithic package was adopted just in particular socio-ecological niches and not across the whole of Sicily (Giannitrapani, 2012). A drying phase across the whole of Italy between 4500 and $3800 \mathrm{cal}$ yr BP due to the so-called $4.2 \mathrm{k}$ cal. yr. seems to have been linked to an overall decline of the population in the Italian peninsula (Fig. 3, Fig. 5a-c) except for Sicily which, instead, experienced substantial population growth in the second half of the fifth millennium BP (Fig. 5d; cf. Pacciarelli et al., 2015). This could be explained by the fact that the local prehistoric communities of Sicily could have responded more easily to a drying phase given that they had been coping with a drying of the climate from 7000 cal yr BP onwards (Fig. 10).

Magri et al. (2015) identified high percentages of AP (>70\%) across the whole of Italy and densely forested landscapes (AP>90\%) in the Alpine arch and the northern Apennines during the Neolithic and Copper Age. Pollen diagrams from central Italy show a decline of oak woodlands, which were replaced by a more open landscape that could be related to their management in association with early farming and/or drier climatic conditions (Stoddart et al., 2019, pp. 9-10). However, the first clear indication of significant human impact on the landscape seems to occur during the Copper Age when upland AP percentage decreased as a consequence of communities specialised in quarrying and pastoral activities (Biagi et al., 1994; Lowe et al, 1994; Magri et al., 2015; Fig. 3). In this context, it is not always easy to ascertain whether a vegetation change is induced by population dynamics or by climate. For instance, the pollen records from Lake Trifoglietti, in southern Italy, indicate a sharp decrease of AP percentage (from $90 \%$ to $60 \%$ ) in the first half of the fifth millennium $\mathrm{BC}$, perhaps linked to drier climatic conditions coupled with heavy human impact (Joannin et al., 2012; Moser et al., 2017, pp. 120-124). Other pollen records from Sicilian sites such as Gorgo Basso, Biviere di Gela, and Urgo Pietra Giordano show an increase of open landscapes during the period $\sim 400-4100$ cal yr BP, perhaps linked to population growth and an arid climate as suggested by the lower lake levels of Lakes Pergusa and Preola (see Fig. 10; Noti et al., 2009; Tinner et al., 2009, 2016; Di Rita et al., 2018). To summarise, the gradual opening of the Italian landscape during the Middle Holocene could be the result of both the human impact and climate change (Roberts et al., 2019; Stoddart et al., 2019).

\section{Bronze Age and Early Iron Age}

The fourth millennium BP witnessed a broad-spectrum exploitation of the landscape: a wide range of regional landscapes were used, and Bronze Age communities settled both on naturally defensible locations (e.g. hilltops and promontories) and in lowlands such as coastal zones, plateaux and lake basins (Malone \& Stoddart, 1994; Barker, 1999, pp. 17-18; Bietti Sestieri, 2013a). In this period, farming strategies became more intensive, with greater evidence (in terms of both production and consumption) for cereals, newly cultivated trees/vines (e.g. Olea, Juglans, Castanea, and Vitis), and mixed livestock (but with a prevalence of sheep and goat), which also became a source of secondary products such as milk and wool (Bietti Sestieri, 
2013a, p. 635; Mercuri et al., 2013). The Italian peninsula saw a further apparent increase of population during the Early Bronze Age (c.4200-3600 cal yr BP), and demographic growth thereafter appears to have continued during the Middle (c.3600-3300 cal yr BP) and Late/Final Bronze Age (c.3300-2900 cal yr BP, Fig. 3; cf. Gennaro \& Peroni, 1986; Bettelli et al., 2004; Nicolis, 2013, pp. 695-697). Middle Bronze Age settlements were located across both the lowlands and highlands and continued to be sustained by a mixed economy based on intensive agriculture and animal husbandry (Peroni, 1996, pp. 202-204; Costantini \& Costantini Biasini, 2007). In contrast, during the Late Bronze Age (c.3300-3100 cal yr BP) there is a marked abandonment of the lowlands, with a switch to settlements mainly on hilltops and other naturally defended locations (Barker \& Stoddart, 1994, 154; Di Gennaro, 2006).

Despite an overall dramatic increase of population across Italy since the Early Bronze Age (Fig. 3c, d), the SPDs of calibrated radiocarbon dates indicate strikingly different regional patterns (Table 5). Especially noteworthy are the statistically significant negative correlation coefficients between adjacent regions on the Italian mainland during this time period; that is, between northern and central Italy, and between central and southern Italy. Demographic 'booms' in one region were matched by 'busts' in neighbouring ones, opening the possibility that regions may have flourished - at least in part—at the expense of their neighbours, or that local populations migrated from one region to another. In northern Italy, population grew dramatically in the Early Bronze Age and peaked during the Middle/Late Bronze Age (c.3600-3200 cal yr BP ) with the establishment of the Terramare culture (Fig. 5a), characterised by large pile-dwelling settlements that spread from the central part of the Po Valley down to the Apennines (Fasani, 2002; Bernabò Brea, 2009, p. 11; Nicolis, 2013, pp. 696-697; Capuzzo et al., 2018, 15-16). This abrupt and substantial population growth could have been triggered by the introduction of new technologies such as the plough, crop rotation, stabling and the switch from fire-fallow cultivation to irrigated crops (Cremaschi, 2009; Nicolis, 2013, p. 697). A significant and abrupt decline of population occurred in the Final Bronze Age after c.3200 cal yr BP (Fig. 5a), marking the end of the Terramare culture (Bernabò Brea, 2009, p. 11; Nicolis, 2013, p. 697). However, the crisis of the pile-dwelling Terramare culture seems not to have affected some areas around Verona and the Po delta, where sites such as Frattessina reached a size greater than 20 ha and thrived as an important hub of long-distance trade in the Adriatic and the central Mediterranean (Bellintani, 2000; Bietti Sestieri, 2008; Bietti Sestieri et al., 2019).

Unlike northern Italy, central Italy did not see a dramatic increase of population with the onset of the Bronze Age and was strongly depopulated during the Middle Bronze Age (Fig. 5b; see also Bettelli et al., 2004, pp. 335-336). However, this pattern contradicts some current interpretations of continued population growth throughout the fourth millennium BP (Bietti Sestieri, 2010; Minniti, 2012) and may have been affected by research biases promoting the importance of the Final Bronze Age compared to the earlier phases (cf. Barbaro, 2010). Further radical changes in settlement patterning then occurred between the Final Bronze Age (c.3200-2800 cal yr BP) and the Early Iron Age (c.3200-2800 cal yr BP), with substantial demographic growth and the abandonment of many of the small-sized dispersed hilltop 


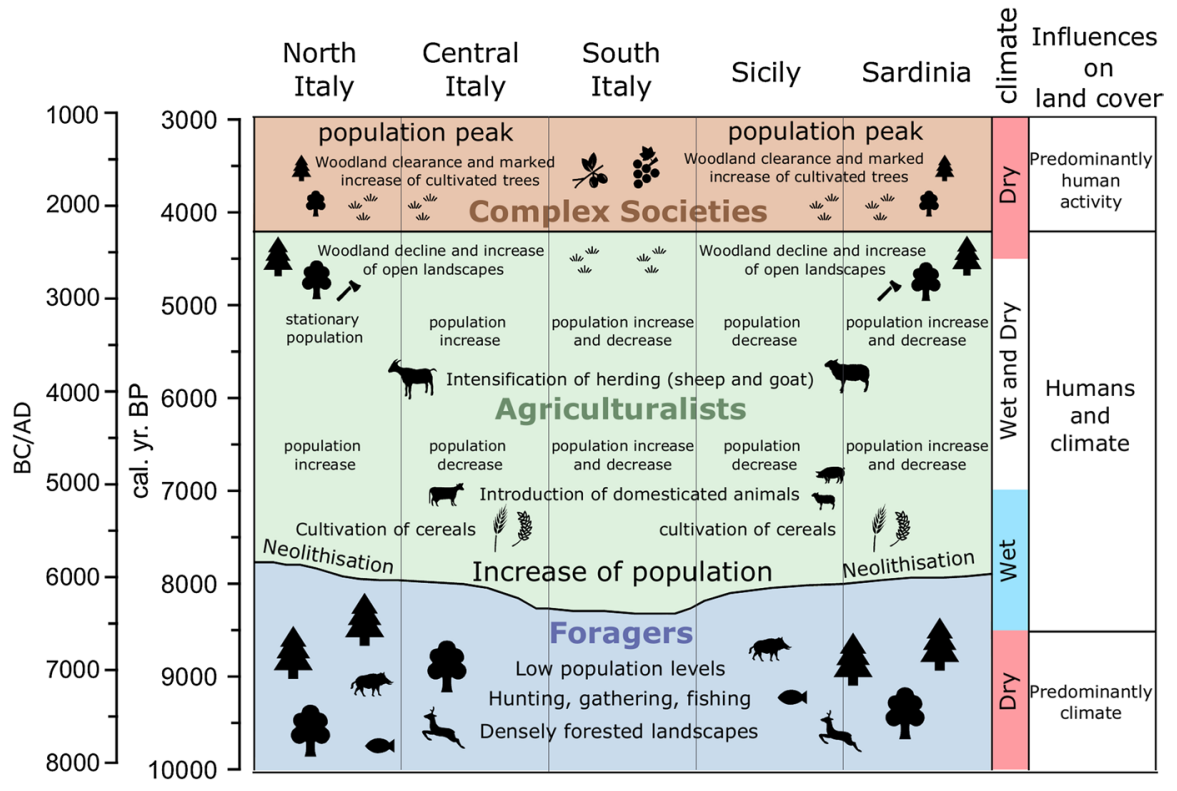

Fig. 11 Schematic diagram of demographic, environmental and climatic trends in prehistoric Italy

villages (those generally about $2 / 3$ ha in size) and the concentration of population in larger nucleated and centralised urban centres (sometimes measuring over 100 ha) located in the lowlands and on plateaux (Peroni, 2000; Pacciarelli, 2001; Redhouse \& Stoddart, 2011; Fulminante, 2014, pp. 44-47; Alessandri, 2015, 2016; Stoddart, 2016, fig. 11; Palmisano et al., 2017, pp. 65-68; Stoddart et al., 2019). This process culminated in full-scale urbanisation and early-state societies during the Late Iron Age (c. 2700-2500 cal yr BP) and Archaic period (c.2500-2400 cal yr BP ), when the political landscape was fragmented into several city-states located at an average distance of 15-25 km from each other (Vanzetti, 2002; Riva, 2009, pp. 12-37; Fulminante et al., 2017; Prignano et al., 2019; Stoddart et al., 2020).

According to the inferred SPD of radiocarbon dates (Fig. 5c), during the Early and Middle Bronze Age southern Italy experienced substantial demographic growth followed by the same demographic crisis that occurred in the Po Plain in the Late Bronze Age with the marked abandonment of sites located both in the hinterland and, to a lesser extent, in the coastal zones (Bettelli et al., 2004; Burgers \& Recchia, 2009; Bietti Sestieri, 2013a, p. 647; Iacono, 2018, pp. 69-71, 119-120). The decrease of population persisted in the Early Iron Age, a period characterised by a lower degree of territorial and political organisation than the Middle and Late Bronze Age (Bietti Sestieri, 2013a, pp. 647-650; Foxhall, 2018). However, this pattern is not ubiquitous, as some archaeological surveys from Calabria show a pattern of settlement nucleation where population is concentrated in a lower number of larger sites reaching up to 50 ha (e.g. Serre d'Altilia), such as those distributed in the areas of Crotone and Sibari (Vallino, 1984; Marino, 1998; Bettelli et al., 2004, pp. 327-334). Furthermore, most of the available archaeological evidence for 
southern Italy is based on burial evidence and few well-excavated settlements have been published, which in turn may lead to underestimation of the population level inferred from radiocarbon dates. During the Early Bronze Age, the territory of Sicily was intensively occupied and the settlements distributed on hills and plains in order to exploit the fertile agricultural soils (Bietti Sestieri, 2013b, p. 657; Fig. 5d). In this period, the island was also involved in long-distance contacts with the Eastern Mediterranean and experienced the earliest forms of centralised religious and economic activities (Castellana, 1998; Voza, 1999, pp. 17-23). After a decrease in the population between 3800 and $3300 \mathrm{cal} \mathrm{yr} \mathrm{BP}$, the region experienced another demographic boom during the Late Bronze Age, perhaps related to the migration of people from the coast of Calabria and the consequent introduction of the Ausonian culture (Tusa, 1999, p. 556; Bietti Sestieri, 2013b, p. 663; Albanese Procelli, 2016; Fig. 5d). This picture seems to be corroborated by the demographic trends from some archaeological surveys carried out in the Erei highlands, in Enna's hinterland (Giannitrapani, 2012; Valbruzzi, 2009). In Sardinia, a rapid increase of the population occurred from $3500 \mathrm{cal}$ yr BP and peaked during the Late and Final Bronze Age (Fig. 5e), when the Nuragic culture reached its apex and multi-towered nuraghi with massive stone enclosures and bastions started to be built (Campus et al., 2010; Lo Schiavo, 2013, p. 676; Vanzetti et al., 2013). However, this pattern is further augmented by research biases focussing particularly in the Late and Final Bronze Ages of Sardinia.

During the Late Holocene, despite drier climatic conditions from $4500 \mathrm{cal} \mathrm{yr}$ BP onwards indicated by the available palaeoclimatic records (Fig. 8), the overall trend is a dramatic population increase, negatively correlated with climate (Figs. 7, $8,9,10)$. In fact, in this period, we see a decoupling of demographic trends and climate because population was less vulnerable to climatic shifts due to advances in technologies for coping with drought and food stress, and extensive trade networks and logistic infrastructures typical of more complex societies (Roberts et al., 2019, pp. 932-933). Nevertheless, the 4.2 ka climate event does coincide with the transition between the Copper and Early Bronze Ages across Italy, suggesting that climate instability at this time may have triggered new cultural adaptations. Furthermore, patterns on a regional scale can depict a different scenario as local communities can experience different strategies in response to social and environmental stress. In northern Italy, the population increased significantly despite an abrupt shift towards arid climatic conditions from 4000 cal yr BP (Fig. 7). The demographic collapse and the consequent crisis of the Terramare culture in the Final Bronze Age seems, instead, to be correlated with a more arid climate, as suggested by the palaeoclimate records from Lakes Frassino and Ledro (Cremaschi, 2016; Capuzzo et al., 2018, p. 19). However, it is doubtful that the climate alone was responsible for the demographic crisis, since the records from Ernesto Cave do not show drier conditions and it is not to be excluded that the depletion and overexploitation of resources played an important role in the collapse of the local Bronze Age societies (Cremaschi, 2009; Capuzzo et al., 2018, p. 21; Teržan \& de Marinis, 2018, p. 4). In central Italy, the population is negatively correlated with climate and it grew substantially during the Final Bronze Age and the Early Iron Age despite more arid conditions and the pronounced sub-centennial rainfall fluctuations between moist and dry conditions 
(Fig. 8). In Southern Italy, the population increased dramatically during the Early and Middle Bronze Age despite drier climatic conditions (Fig. 9). However, it seems that the population fluctuations are positively correlated during the third millennium BP when compared with the palaeoclimatic record from the Gulf of Taranto (Fig. 9:7). In Sicily, population and climate decouple completely during the Bronze Age and are negatively correlated (Fig. 10).

To summarise, despite some inter-regional variations, it appears that Bronze and Iron Age Italian communities were able to develop subsistence strategies and technology to cope with climatic stress. The $3.2 \mathrm{k}$ cal yr BP event that triggered the political and societal collapse of the Greek and Eastern Mediterranean polities seems not to have severely affected the Italian peninsula and islands (Langgut et al., 2013; Cline, 2015; Kaniewski et al., 2015, Kaniewski et al., 2019). An exception in northern Italy may be the Terramare culture, whose collapse could be the result of the carrying capacity being exceeded, exacerbated by less favourable climatic conditions. Of course, the inferred decline in population in southern Italy could be an underestimation due to the ephemeral archaeological evidence (mostly based on burials) for the early Iron Age. In addition, according to the pan-Mediterranean hydro-climatic study by Finné et al. (2019), the magnitude of the $3.2 \mathrm{k}$ cal yr BP event was less severe in Italy as compared to the Eastern Mediterranean and, therefore, prehistoric Italian communities may have been less severely impacted by it.

During the fourth millennium BP, the landscapes began to be anthropogenised and characterised by a larger-scale agricultural and herd-based economy that caused woodland clearance and a marked increase of cultivated trees (Mercuri et al., 2013). Work by Magri et al., (2015, pp. 269-270) shows that during the Bronze Age, and more noticeably in the later Iron Age, the Italian peninsula experienced notable deforestation with AP often lower than $70 \%$. In particular, in northern Italy there was a substantial opening-up of deciduous oak forests and an expansion of pasturelands that could be linked to both greater aridity and intensive anthropogenic land use (Cremaschi et al., 2016). In central Italy, the dramatic growth of population during the Final Bronze Age and the Early Iron Age also had a significant impact on landscape cover, with an abrupt increase in cultivated trees or vines (e.g. Olea, Juglans, Castanea, and Vitis) and a marked landscape openness/forest loss (Di Rita et al., 2018; Magri \& Sadori, 1999; Mercuri et al., 2002; Stoddart et al., 2019). In southern Italy, the pollen records from Calabria and Campania (e.g. Avella, Palma Campanile, Lake Trifoglietti, Lake Forano and Fontana Manca) suggest a marked decline in forest cover from around 3700 cal yr BP, in step with a significant increase in the population that strongly modified the landscape (Moser et al., 2017; Saccoccio et al., 2013; Sevink et al., 2019). In addition, from 4000 cal yr BP Olea cultivation started spreading in areas with a typical Mediterranean climate, such as Apulia and Sicily, perhaps as a consequence of enhanced human activity in the area (Di Rita \& Magri, 2009; Magri et al., 2015, p. 281). In Sicily, however, after a forest decline between 4700 and 4100 cal yr BP perhaps related to drier climatic conditions, the pollen records (Biviere di Gela, Lake Pergusa, Gorgo Basso) seem to indicate a forest regeneration from 4100 to $2900 \mathrm{cal}$ yr BP, despite an increase of the local population (Tinner et al., 2009; Magny et al., 2011; Moser et al., 2017, 124; Di Rita et al., 2018). However, the AP percentage ( 50\%) during the 4th millennium 
BP is still lower than that during the Middle Holocene and indicates a fairly open landscape (Magri et al., 2015, pp. 269-270). In Sardinia, the pollen records from Mistras Lagoon, near the ancient Tharros, indicate that-as in Sicily-during the fourth millennium BP the AP percentage was stable and did not experience substantial change (Di Rita \& Melis, 2013, p. 4279). However, the pollen diagram shows an increase of cereals and Vitis during the Bronze Age, pointing to a major human activity and a prevailing arable farming economy (Bakels, 2002; Di Rita \& Melis, 2013, p. 4281).

\section{Conclusion}

This paper has shown, for the first time, the various long-term demographic trends occurring over the Italian peninsula and islands from the Mesolithic to the early Iron Age (10,000 to $2800 \mathrm{cal}$ yr BP ). We used SPDs of calibrated radiocarbon dates to identify population trajectories in five different regions of Italy. These show good spatial coherence between regions prior to $7000 \mathrm{cal}$ yr BP (e.g. Mesolithic to Early Neolithic), increasing regionalisation of demographic patterns from the Middle Neolithic to the end of the Copper Age ( 7000 to $\sim 200$ cal yr BP ), and marked inter-regional contrasts during the Bronze and Early Iron Ages ( 4200 to 2800 cal $\mathrm{yr} \mathrm{BP}$ ). In the last time period, population trends in adjacent regions were frequently the inverse of one another, suggesting the possibility that booms in one region may have had negative consequences for neighbouring populations. However, population trends are best estimated using a multi-proxy approach in order to compare independent archaeological indices and statistically assess the extent to which they converge and diverge from one another. This approach would allow us to explore the strengths and weaknesses of each line of evidence and to build more robust narratives, both over the long run and in specific well-defined periods. Unfortunately, high quality integrated datasets of archaeological survey data are not (yet) available for the whole of Italy and the lack of digital repositories for this kind of data requires a massive effort of digitisation. However, the overall agreement between the SPDs of calibrated radiocarbon dates and the settlement-based proxies shown in former studies across several regions of the Mediterranean and Italy suggests that SPDs can be quite a reliable indicator for reconstructing past population dynamics up to 2800 cal yr BP. Nevertheless, given the patchiness of the available data, we are aware of the caveats necessary in inferring population trends by using only SPDs of calibrated radiocarbon dates and our results should be considered preliminary.

We have also summarised palaeoclimate records from the Italian peninsula and nearby sites in order to explore the degree to which climate change impacted human populations. We examined this possible causal relationship by adopting a spatio-temporal approach to assess whether patterns of convergence and divergence between demographic and palaeoclimatic proxies vary at different geographical scales of analysis and within specific periods. Results show either no statistical correlation at all or an overall negative correlation between population fluctuations and hydro-climate patterns. In other words, human populations grew and declined independently from long-term climate trajectories, and causal relationships operated, instead, on 
shorter timespans, as shown by the 500-year moving window correlations. It could be argued that wetter conditions in northern Italy over the whole Holocene gave an advantage to local populations if compared with more arid conditions in the rest of the peninsula and Sicily. However, a simplistic cause-and-effect relationship is unconvincing in Italy given its spatial inhomogeneity in terms of hydro-climatic and topographic variability. The prehistoric communities of Italy responded differently to the climatic shifts, and climatic adversity may have prompted technological innovations and new adaptation strategies rather than causing societal collapse (e.g. mobility, crop rotation and diversification, the switch from fire-fallow cultivation to irrigated crops, group fission; Cremaschi, 2009; Nicolis, 2013, p. 697; Mercuri et al., 2011; Leppard, 2014). A positive correlation between climatic moisture and population is, nonetheless, evident in some regions for specific limited periods of time. For instance, the dramatic increase of population in the Early Neolithic is correlated positively with a trend towards wetter climatic conditions from $8.5 \mathrm{k} \mathrm{cal}$. yr. to $7.0 \mathrm{k}$ cal yr BP that would have favoured the demic diffusion of farming from western Greece and the Balkans to south-eastern Italy and northwards (Fig. 11). A similar association has been identified for Greece (Roberts et al., 2019, Fig. 5b). Despite a dramatic increase of population with the onset of the Neolithic, it seems that the human footprint did not play a determinant role in the evolution of the Early and Middle Holocene landscapes as fluctuations in the percentage of arboreal pollen seem to be more related to climate change than to human activity. Another clear positive correlation between demographic and climatic trends occurred in the second half of the fifth millennium BP ( 4500-4000 cal yr BP) when the population decreased across the whole of Italy during a prolonged drying phase, before recovering in the Early Bronze Age. However, in the Late Holocene, the demographic fluctuations and climatic shifts decoupled as a result of advances in technology and the extensive social networks that enhanced the ability of local Bronze and Iron Age communities to deal with environmental and food stress. The late-Holocene landscape was, in consequence, increasingly anthropogenised and characterised by a large-scale agricultural and herd-based economy that caused pronounced woodland clearance and a proliferation of cultivated trees (Fig. 11). Unlike in the eastern Mediterranean, the $3.2 \mathrm{k}$ cal. yr. event seems not to have negatively impacted prehistoric Italian communities directly. This might be due to the variety of subsistence strategies developed to cope with climate fluctuations on the one hand, and to more resilient social and political organisation on the other.

To summarise, it seems that a closer relationship between climate and demography occurred in the Early and Middle Holocene, although only for limited time periods, before the emergence of complex stratified societies in the later Bronze and Iron Ages (Fig. 11; cf. Roberts et al., 2019).

A future research endeavour will be to compare the climatic and demographic trends with long-term vegetation changes inferred from the existing fossil pollen records distributed over all Italy. This would allow us to assess not only a possible causal linkage between climate and population but also the impact of climate change on vegetation and the impact of human populations on the landscape. Furthermore, the SPDs of calibrated radiocarbon dates need to be integrated with other archaeological indices (e.g. raw site count, aggregated estimated settlement size) in order to 
produce more robust results and trace socio-environmental trajectories over a chronological spectrum extending up to Medieval and post-Medieval times.

\section{Editor's Note}

The publication by JWP of two independently-researched palaeodemographic syntheses covering a similar region and timespan affords a rare opportunity to reflect on the relationship between theories, methods and results in our discipline. In particular, it provides a context for assessing the potential of reproducible research for increasing archaeological knowledge security. In order to make the most of this conjunction, the Editor-in-Chief exceptionally invited each team to consider the other's results. These invitations were accepted and, while the empirical contents of each paper remain unaltered from their peer-reviewed acceptance, each now concludes with a short commentary reflecting on the similarities and differences.

Timothy Taylor, Comenius University in Bratislava, August 2021

\section{Commentary: Palmisano et al. 2021 on Parkinson et al., 2021}

It is excellent to see the paper 'Radiocarbon dated trends and central Mediterranean prehistory' by Parkinson et al. (2021). It represents, in tandem with our study, a rare example in archaeology of the kind of reproducible research commonly adopted in natural science and medicine (see Büntgen et al., 2021 for a recent example using tree ring data). In our case, the two studies were conducted independently and are consequently not identical methodologically. Nevertheless, the primary datasets, the regional classification of Italy and the statistical methods are all closely comparable, so that very similar results are provided by the two studies.

Both papers build on an initial date sample for central Italy published in Palmisano et al. (2017, 2018), as well as extant datasets and other sources. The two papers have imposed a screening process to remove environmental dates with no obvious anthropogenic origin. If we compare the overlapping regions of Italy (mainland, including Sicily and Sardinia) then the number of recovered dates is similar: Palmisano et al. (this paper) $n=4010$; Parkinson et al. (2021) $n=3610$ (see Table 1). The difference in the total number of radiocarbon dates could be due to slight differences in the chronological scope of the two studies. Our paper enables radiocarbon dates from 11,000 to 1500 uncal yr BP, while the paper by Parkinson et al. (2021) states that the calibrated radiocarbon dates span from 8000 to $500 \mathrm{BC}$. However, their Fig. 3 shows a broader chronological scope, from 10,000 to $1 \mathrm{BC}$. The regional number of radiocarbon dates is quite similar in the two studies, with greater difference occurring in Sicily and southern Italy, where our paper counts a total number of radiocarbon dates respectively higher by $19.3 \%(n=278$ vs. 233$)$ and $56.5 \%$ ( $n=784$ vs. 501) than the one provided by Parkinson et al. (2021) (see Table 6).

The two papers use slightly different methods for assessing time series of aggregate radiocarbon dates: in the present paper, we use the more common basic summed probability distribution (SPD) approach supported by a combination of 
Table 6 A comparison of the number of archaeological sites and radiocarbon dates used in the papers by Parkinson et al. (2021) and Palmisano et al. (2021 - the current paper)

\begin{tabular}{lllll}
\hline Region & $\begin{array}{l}\text { No. sites (Parkinson } \\
\text { et al., 2021) }\end{array}$ & $\begin{array}{l}\text { No. dates (Parkinson } \\
\text { et al., 2021) }\end{array}$ & $\begin{array}{l}\text { No. Sites (Palm- } \\
\text { isano et al. 2021) }\end{array}$ & $\begin{array}{l}\text { No. Dates } \\
\text { (Palmisano et al. } \\
\text { 2021) }\end{array}$ \\
\hline Northern Italy & 350 & 1566 & 396 & 1677 \\
Central Italy & 266 & 1047 & 248 & 1005 \\
Southern Italy & 133 & 501 & 174 & 784 \\
Sardinia & 79 & 263 & 81 & 266 \\
Sicily & 47 & 233 & 48 & 278 \\
Total & 875 & 3610 & 947 & 4010 \\
\hline
\end{tabular}

model-fitting and regional permutation to assess the reliability of the results, while Parkinson et al. (2021) use a fixed-width kernel density estimator (KDE), supported by a bootstrapped confidence interval. Neither one strongly insists on the primacy of their particular methods and both studies produce essentially similar outcomes (see for comparison Parkinson et al., 2021, Fig. 3; this paper, Figs. 4-5). Parkinson et al. (2021) (rightly in our view) point to the attractiveness of always expressing these time-series with uncertainty (e.g., via KDE bootstrapping) that is immediately obvious to the viewer, although we should point out that a KDE approach is by default one that uses normalised dates that exhibit calibration 'spikes' (see discussion in Weninger et al., 2015; Palmisano et al., 2017; Crema \& Bevan, 2021, pp. 27-29). In our paper we used both SPD and KDE approaches and Figs. 3a, b and 4 show very similar patterns, which is reassuring in suggesting that both methods are valid for inferring past human demographic trends.

Italy has been divided into the same five regions in both studies, enabling intercomparison for the period 7000 to $800 \mathrm{BC}$, from the late Mesolithic to the Final Bronze Age/Early Iron Age. Happily, the resulting SPD of calibrated radiocarbon dates and the KDE curves are almost the same in both studies, indicating a high degree of similarity. The similarity of inferred demographic trends does not mean that the results from either study are necessarily 'correct', because they could be subject to the same biases. Even so, it gives confidence that the analytical methods used produce repeatable outcomes. The only significant difference is a demographic peak in southern Italy during the Bronze Age in the current paper, which is more attenuated in Parkinson et al. (2021). The lack of a substantial increase in population in Southern Italy in the work by Parkinson et al. (2021) could be due to the fact that they did not include in their studies a suite of publications that have recently published radiocarbon dates from the Bronze Age (Alessandri, 2019; Ippolito, 2016; Livadie et al., 2019; Marino, 2020; Pacciarelli et al., 2015; Radina et al., 2017). By contrast, our study highlights a significant increase in population during the Early and Middle Bronze Age, followed by a decline during the Middle and Final Bronze Age, as also shown in the work by Parkinson et al. (2021). In addition, we have restricted the chronological scope of our analysis to before $800 \mathrm{BC}$, as after this period the radiocarbon dates stop being a good proxy for inferring past 
human population dynamics in the Mediterranean basin. This is shown in the crosscomparative work carried out under the Leverhulme Trust-funded project 'Changing the Face of the Mediterranean' (for more details see Bevan et al., 2019; for a comparison between several case studies see Roberts et al., 2019). Therefore, we think that the reconstructed Iron Age population trends in Parkinson et al. (2021) have been overinterpreted and should be treated more cautiously. The decline they detected after $820 \mathrm{BC}$-lasting up to $500 \mathrm{BC}$ in the central Mediterranean, possibly due to worsening climatic conditions - may be overstated, given that works by Palmisano et al. (2017) and Stoddart et al. (2019) making use of multiple proxies (radiocarbon dates, sites raw count, estimated settlement size) do not show this drop. In addition, in central Italy c. 1000-700 BC was a period of centralisation into fewer larger settlements and our data are compatible with multiple ways of modelling this process. Nucleation may have been a response to demographic decline, and a collective solution to the problem of weakening social connections in an otherwise more dispersed settlement system. Alternatively, it may simply reflect a situation where fewer sites are represented by fewer dates.

In the end, the two papers both adopt an explicitly regional, comparative perspective but extend this in different ways, with Parkinson et al. (2021) favouring additional attention to the radiocarbon time series exhibited by neighbouring regions of the Mediterranean, while the current paper favours additional attention to the available regional palaeoenvironmental evidence. The pan-regional comparison by Parkinson et al. (2021) between the central Mediterranean and other neighbouring European regions from the Late Mesolithic to the Iron Age shows a series of longterm 'cycles' of population growth (booms) and decline (busts) in most regions and depicts demographic trends similar to those inferred in former studies making use of SPD of calibrated radiocarbon dates (e.g., Roberts et al., 2019; Shennan et al., 2013). These 'cycles' were not synchronous between regions, as shown by the pronounced booms related to the spread of agriculture from the Eastern Mediterranean to continental Europe, reflecting the 'wave-of-advance' model (Ammerman \& Cavalli-Sforza 1979).

To conclude, the two studies provide a set of complementary methods and data that further contribute to the advancement of research dealing with population dynamics and human-environment interaction in the central Mediterranean. The dissemination of datasets and $\mathrm{R}$ scripts provides an excellent tool to check the reliability of the analyses and foster collaborative and fruitful discussion about the topic. We believe that a step forward would be to augment the palaeodemographic proxies by making use not only of radiocarbon dates but also of evidence from archaeological surveys such as raw site counts and summed estimated settlement sizes in order to provide more robust results.

\section{Appendix A: Reproducibility and Supplementary Data}

The dataset AIDA (Archive of Italian radiocarbon DAtes) related to this paper provides a collection of 4010 radiocarbon dates spanning from 11,000 to 1500 uncal yr BP and is available via the following links, via Zenodo (https://doi.org/ 
10.5281/zenodo.5156104) and Github (https://github.com/apalmisano82/AIDA). In addition, we provide a script written in $\mathrm{R}$ statistical language to reproduce the analyses and figures related to the paper at the following link: https://doi.org/10. 5281/zenodo.5158166

Acknowledgements This research was funded by the Leverhulme Trust (grant number RPG-2015-031) for the project 'Changing the face of the Mediterranean: land cover and population since the advent of farming', a Plymouth-UCL collaboration. We are also grateful to Silvia Frisia, Andrea Borsato, Giuseppe Siani, and Giovanni Zanchetta for generously providing the palaeoclimate data for this study.

Funding Open Access funding enabled and organized by Projekt DEAL.

Open Access This article is licensed under a Creative Commons Attribution 4.0 International License, which permits use, sharing, adaptation, distribution and reproduction in any medium or format, as long as you give appropriate credit to the original author(s) and the source, provide a link to the Creative Commons licence, and indicate if changes were made. The images or other third party material in this article are included in the article's Creative Commons licence, unless indicated otherwise in a credit line to the material. If material is not included in the article's Creative Commons licence and your intended use is not permitted by statutory regulation or exceeds the permitted use, you will need to obtain permission directly from the copyright holder. To view a copy of this licence, visit http://creativecommons.org/licen ses/by/4.0/.

\section{References}

Albanese Procelli, R. M. (2016). Gli indigeni della Sicilia tra la Prima e la Seconda Età del Ferro: Il contesto locale della 'prima colonizzazione.' In L. Donnellan, V. Nizzo, \& G. J. Burgers (Eds.), Contexts of early colonization: Papers of the Royal Netherlands Institute in Rome, 64 (pp. 199210). Palombi.

Alessandri, L. (2015). Exploring territories: Bubble model and minimum number of contemporary settlements, a case study from Etruria and Latium Vetus from the Early Bronze Age to the Early Iron Age. Origini, XXXVII, 175-199.

Alessandri, L. (2016). Hierarchical and federative polities in protohistoric Latium Vetus: An analysis of Bronze Age and Early Iron Age settlement organization. In P. Attema, J. Seubers, \& S. Willemsen (Eds.), Early states, territories and settlements in protohistoric Central Italy. Corollaria Crustumina 2. Groningen Institute of Archaeology.

Alessandri, L. (2019). The early and Middle Bronze Age (1/2) in South and central Tyrrhenian Italy and their connections with the Avellino eruption: An overview. Quaternary International, 499, 161-185.

Alexander, C. (2005). A Bayesian analysis of the radiocarbon evidence for the spread of the Neolithic in Italy. M.Phil Thesis, Department of Archaeology, Cambridge University

Ammerman, A. J., \& Cavalli-Sforza, L. L. (1984). The Neolithic transition and the genetics of populations in Europe. Princeton University Press.

Antonioli, F., Cremona, G., Immordino, F., Puglisi, C., Romagnoli, C., Silenzi, S., Valpreda, E., \& Verrubbi, V. (2002). New data on the Holocenic sea-level rise in NW Sicily (Central Mediterranean Sea). Global and Planetary Change, 34(1-2), 121-140.

Anzidei, A. P. (1987). Il processo di Neolizzazione nel Lazio centro-Meridionale. In Atti della XXVI Riunione Scientifica dell'Istituto Italiano di Preistoria e Protostoria (pp. 173-185). Istituto Italiano di Preistoria e Protostoria.

Anzidei, A. P., Barbaro, B., Carboni, G., Castagna, A., Celant, A., Egidi, R., Favorito, S., Malvone, M., \& Spadoni, D. (2010). Geomorphological and environmental transformations during the recent prehistory: A reconstruction of the landscape and the peopling of the territory south-east of Rome. The Colli Albano Volcano Special Publications of IAVCEI, 3, 339-353. 
Anzidei, A. P., \& Zarattini, A. (2007). Il Neolitico e 1'Eneolitico nel Lazio centro-meridionale: Aspetti culturali e scelte insediamentali. In Atti della XL Riunione Scientifica dell'Istituto Italiano di Preistoria e Protostoria (pp. 79-100). Istituto Italiano di Preistoria e Protostoria.

Arcà, A. (2004). The topographic engravings of Alpine rock-art: Fields, settlements and agricultural landscapes. In C. Chippindale \& G. Nash (Eds.), Pictures in place: The figured landscapes of rock-art (pp. 318-349). Cambridge University Press.

Armit, I., Swindles, G. T., \& Becker, K. (2013). From dates to demography in later prehistoric Ireland? Experimental approaches to the meta-analysis of large 14C data-sets. Journal of Archaeological Science, 40(1), 433-438.

Atzeni, E. (1987). Il neolitico della Sardgena. In Atti della XXVI Riunione Scientifica della Istituto Italiano di Preistoria e Protostoria (pp. 381-398). Istituto Italiano di Preistoria e Protostoria

Bagolini, B. (1980). Introduzione al neolitico dell'Italia settentrioneale nel quadro dell'evoluzione della prime culture agricole europee. Societa' Naturalisti 'Silvia Zenari.'

Bagolini, B., \& Biagi, P. (1990). The radiocarbon chronology of the Neolithic and Copper Age of northern Italy. Oxford Journal of Archaeology, 9, 1-23.

Bakels, C. (2002). Plant remains from Sardinia, Italy, with notes on barley and grape. Vegetation History and Archaeobotany, 11, 3-8.

Barbaro, B. (2010). Insediamenti, aree funerari ed entita territoriali in Etruria meridionale nel Bronzo Finale. All'Insegna del Giglio.

Barker, G. (1975). Prehistoric territories and economies in Central Italy. In E. Higgs (Ed.), Palaeoeconomy (pp. 111-175). Cambridge University Press.

Barker, G. (1981). Landscape and society: Prehistoric central Italy. Academic Press.

Barker, G. (1999). Hunting and farming in prehistoric Italy: Changing perspectives on landscape and society. Papers of the British School at Rome, 67, 1-36.

Barker, G., Biagi, P., Castelletti, L., Cremaschi, M., \& Nisbet, R. (1987). Sussistenza, economia ed ambiente nel Neolitico dell'Italia settentrionale. In Atti del XXVI Riunione Scientifica: Il neolitico in Italia, 2 (pp. 103-117). Istituto Italiano di Preistoria e Protostoria.

Barker, G., \& Stoddart, S. (1994). The Bronze Age of central Italy: c. 2000-900 BC. In C. Mathers \& S. Stoddart (Eds.), Development and decline in the Mediterranean Bronze Age (pp. 145-165). John Collis.

Baroni, C., Zanchetta, G., Fallick, A. E., \& Longinelli, A. (2006). Mollusca stable isotope record of a core from Lake Frassino, northern Italy: Hydrological and climatic changes during the last 14 ka. The Holocene, 16(6), 827-837.

Becerra-Valdivia, L., Leal-Cervantes, R., Wood, R., \& Higham, T. (2020). Challenges in sample processing within radiocarbon dating and their impact in 14C-dates-as-data studies. Journal of Archaeological Science, 113, 105043.

Bellini, C., Mariotti Lippi, M., \& Montanari, C. (2009). The Holocene landscape history of the NW Italian coasts. The Holocene, 19, 1161-1172.

Bellini, C., Mariotti Lippi, M., Mori Secci, M., Aranguren, B., \& Perazzi, P. (2008). Plant gathering and cultivation in prehistoric Tuscany (Italy). Vegetation History and Archaeobotany, 17, 103-112.

Bellintani, P. (2000). Il Medio Polesine tra la tarda Età del Bronzo e l'inizio dell'Età del Ferro. In M. Harari \& M. Pearce (Eds.), Il Protovillanoviano al di qua e al di là dell'Appennino (pp. 47-84). New Press.

Berger, J. F., Shennan, S., Woodbridge, J., Palmisano, A., Mazier, F., Nuninger, L., Guillon, S., Doyen, E., Bégeot, C., Andrieu-Ponel, V., \& Azuara, J. (2019). Holocene land cover and population dynamics in Southern France. The Holocene, 29(5), 776-798.

Bernabò Brea, M. (2009). Le terramare nell'Età del Bronzo. In M. Bernabò Brea \& M. Cremaschi (Eds.), Acqua e civiltà nelle terramare: La vasca votiva di Noceto (pp. 5-16). Skira

Bernabò Brea, M., Cardarelli, A., \& Cremaschi, M. (1997). Le Terramare, la piu' antica civilta' padana. Electa.

Bernabò Brea, M., \& Steffè, G. (1990). Il neolitico antico a Savignano. In B. Sala (Ed.), Nel segno dell'elefante: Geologia, paleontologia e archeologia del territorio di Savignano sul Panaro. El Quatrari.

Bettelli, M., Cardarelli, A., Di Gennaro, F., Levi, S. T., Marino, D., Pacciarelli, M., Peroni, R., Vagnetti, L., \& Vanzetti, A. (2004). L'Eta' del Bronzo Media e Tarda in Calabria. In Atti della XXXVII Riunione Scientifica Preistoria e Protostoria della Calabria (pp. 325-344). Istituto Italiano di Preistoria e Protostoria. 
Bevan, A., Colledge, S., Fuller, D., Fyfe, R., Shennan, S., \& Stevens, C. (2017). Holocene fluctuations in human population demonstrate repeated links to food production and climate. Proceedings of the National Academy of Sciences, 114(49), E10524-E10531.

Bevan, A., \& Crema, E. R. (2021). rcarbon v1.4.2: Calibration and analysis of radiocarbon dates. https:// CRAN.R-project.org/package $=$ rcarbon

Bevan, A., Palmisano, A., Woodbridge, J., Fyfe, R., Roberts, C. N., \& Shennan, S. (2019). The changing face of the Mediterranean - Land cover, demography and environmental change: Introduction and overview. The Holocene, 29(5), 703-707.

Biagi, P. (2003). A review of the Late Mesolithic in Italy and its implications for the Neolithic transition. In A. J. Ammerman \& P. Biagi (Eds.), The widening harvest. The Neolithic transition in Europe: Looking back, looking forward (Vol. 6, pp. 133-156). Archaeological Institute of America.

Biagi, P., Nisbet, R., \& Scaife, R. (1994). Man and vegetation in the southern Alps: The ValcamonicaValtrompa-Valsabbia watershed (northern Italy). In P. Biagi \& J. Nandris (Eds.), Highland zone exploitation in southern Europe. Monografie di Natura Bresciana, 20 (pp. 133-141). Museo Civico di Scienze Naturali di Brescia.

Bietti Sestieri, A. M. (2008). L'Età del Bronzo finale nella penisola italiana. Padusa, XLIV, 7-54.

Bietti Sestieri, A. M. (2010). L'Italia nell'età del bronzo e del ferro: Dalle palafitte a Romolo (2200-700 $a C)$. Carocci.

Bietti Sestieri, A. M. (2013a). Peninsular Italy. In A. Harding \& H. Fokkens (Eds.), The Oxford handbook of the European Bronze Age (pp. 633-652). Oxford University Press.

Bietti Sestieri, A. M. (2013b). The Bronze Age in Sicily. In A. Harding \& H. Fokkens (Eds.), The Oxford Handbook of the European Bronze Age (pp. 653-667). Oxford University Press.

Bietti Sestieri, A. M., Bellintani, P., \& Giardino, C. (Eds.). (2019). Frattesina: Un centro internazionale di produzione e di scambio nella tarda Età del Bronzo del Veneto. Accademia Nazionale dei Lincei.

Bini, M., Zanchetta, G., Persoiu, A., Cartier, R., Català, A., Cacho, I., Dean, J. R., Di Rita, F., Drysdale, R. N., Finnè, M., Isola, I., Jalali, B., Lirer, F., Magri, D., Masi, A., Marks, L., Mercuri, A. M., Peyron, O., Sadori, L., ... Brisset, E. (2019). The 4.2 ka BP event in the Mediterranean region: an overview. Climate of the past, 15, 555-577.

Bintliff, J., \& Sbonias, K. (1999). Reconstructing past population trend in Mediterranean Europe (3000 $B C-1800 A D)$. Oxbow.

Bocquet-Appel, J.-P., Naji, S., Vander Linden, M., \& Kozlowski, J. K. (2009). Detection of diffusion and contact zones of early farming in Europe from the space-time distribution of 14C dates. Journal of Archaeological Science, 36, 807-820.

Branch, N. P., Black, S., Maggi, R., \& Marini, N. A. (2014). The Neolithisation of Liguria (NW Italy): An environmental archaeological and palaeoenvironmental perspective. Environmental Archaeology, 19(3), 196-213.

Broglio, A. (1992). Mountain sites in the context of the North-East Italian Upper Palaeolithic and Mesolithic. Preistoria Alpina, 28, 293-310.

Bronk Ramsey, C. (2017). Methods for summarizing radiocarbon datasets. Radiocarbon, 59(6), 1809-1833.

Brown, W. A. (2017). The past and future of growth rate estimation in demographic temporal frequency analysis: Biodemographic interpretability and the ascendance of dynamic growth models. Journal of Archaeological Science, 80, 96-108.

Büntgen, U., Allen, K., Anchukaitis, K. J., Arseneault, D., Boucher, É., Bräuning, A., Chatterjee, S., Cherubini, P., Churakova, O. V., Corona, C., \& Gennaretti, F. (2021). The influence of decisionmaking in tree ring-based climate reconstructions. Nature Communications, 12(1), 1-10.

Burgers, G.-J., \& Recchia, G. (Eds.). (2009). Ricognizioni archeologiche sull'altopiano delle Murge: La carta archeologica del territorio di Cisternino (Brindisi). C. Grenzi.

Calvi Rezia, G. (1980). La ceramica impressa di Pienza (Toscana) e quella di Basi in Corsica. Rivista Scienze Preistoriche, 35, 323-333.

Campus, F., Leonelli, V., \& Lo Schiavo, F. (2010). La transizione culturale dall'età del bronzo all'età del ferro nella Sardegna nuragica in relazione con l'Italia tirrenica. Bollettino Di Archeologia Online, $1,62-76$.

Capuzzo, G., Boaretto, E., \& Barceló, J. A. (2014). EUBAR: A database of 14C measurements for the European Bronze Age: A Bayesian analysis of 14C-dated archaeological contexts from Northern Italy and Southern France. Radiocarbon, 56(2), 851-869. 
Capuzzo, G., Zanon, M., Dal Corso, M., Kirleis, W., \& Barceló, J. A. (2018). Highly diverse Bronze Age population dynamics in central-southern Europe and their response to regional climatic patterns. PLOS ONE, 13(8), e0200709.

Cardarelli, A. (2010). The collapse of the Terramare culture and growth of new economic and social systems during the Late Bronze Age in Italy. Scienze Dell'antichità, 15, 449-520.

Cassano, S. M., Cazzella, A., Manfredini, A., \& Moscoloni, M. (Eds.). (1987). Coppa Nevigata e il suo territorio: Testimonianze archeologiche dal VII al II millennio a.C. Quasar.

Cassano, S. M., \& Manfredini, A. (Eds.). (1983). Studi sul Neolitico del Tavoliere della Puglia: Indagine territoriale in un'area-campione. Archaeopress.

Castagnoli, F. (1974). La carta archeologica d'Italia e gli studi di topografia antica. In Ricognizione archeologica e documentazione cartografica. Quaderni dell'Istituto di Topografia Antica dell'Università di Roma, 6 (pp. 7-17). de Luca.

Castellana, G. (1998). Il santuario castellucciano di Monte Grande e l'approvvigionamento dello zolfo nel Mediterraneo nell'Età del Bronzo. Regione Sicilia.

Cherry, J. F. (1983). Frogs round the pond: Perspectives on current archaeological survey projects in the Mediterranean region. In D. R. Keller \& D. W. Rupp (Eds.), Archaeological survey in the Mediterranean region (pp. 375-416). British Archaeological Reports.

Cline, E. H. (2015). 1177 BC: The year civilization collapsed. Princeton University Press.

Colonese, A. C., Lo Vetro, D., \& Martini, F. (2014). Holocene coastal change and intertidal mollusc exploitation in the central Mediterranean: Variations in shell size and morphology at Grotta d'Oriente (Sicily). Archaeofauna, 23, 181-192.

Colombaroli, D., Tinner, W., Van Leeuwen, J., Noti, R., Vescovi, E., Vannière, B., Magny, M., Schmidtt, R., \& Bugman, H. (2009). Response of broadleaved evergreen Mediterranean forest vegetation to fire disturbance during the Holocene: Insights from the peri-Adriatic region. Journal of Biogeography, 36(2), 314-326.

Colombaroli, D., Vannière, B., Chapron, E., Magny, M., \& Tinner, W. (2008). Fire-vegetation interactions during the Mesolithic-Neolithic transition at Lago dell'Accesa, Tuscany, Italy. The Holocene, 18, 679-692.

Contreras, D. A., \& Meadows, J. (2014). Summed radiocarbon calibrations as a population proxy: A critical evaluation using a realistic simulation approach. Journal of Archaeological Science, 52, 591-608.

Corridi, C., \& Moroni, A. (1993). I materali della Capanna di Norchia conservati al Museo archeologico di Perugia: Industria litica, ossea e resti fauna. Bulletino Di Paletnologia Italiana, 84(II), 381-434.

Costantini, L., \& Costantini Biasini, L. (2007). Economia agricola del Lazio a sud del Tevere tra Bronzo antico e Bronzo medio. In Atti della XL riunione scientifica Istituto Italiano di Preistoria e Protostoria: Strategie di insediamento fra Lazio e Campania in età preistorica e protostorica. Roma, Napoli, Pompei, 30 Novembr -3 Dicembre 2005 (pp. 787-801). Istituto Italiano di Preistoria e Protostoria.

Crema, E. R., \& Bevan, A. (2021). Inference from large sets of radiocarbon dates: Software and methods. Radiocarbon, 63(1), 23-39.

Crema, E. R., Bevan, A., \& Shennan, S. (2017). Spatio-temporal approaches to archaeological radiocarbon dates. Journal of Archaeological Science, 87, 1-9.

Crema, E. R., Habu, J., Kobayashi, K., \& Madella, M. (2016). Summed probability distribution of 14C dates suggests regional divergences in the population dynamics of the Jomon period in eastern Japan. PLoS ONE, 11(4), e0154809.

Cremaschi, M. (2009). Foreste, terre coltivate ed acque, l'originalità del progetto terramaricolo. In M. Bernabò Brea, \& M. Cremaschi (Eds.), Acqua e civiltà nelle Terramare: La vasca votiva di Noceto (pp. 34-42). Milan: Università degli Studi di Milano, Skira.

Cremaschi, M., Mercuri, A. M., Torri, P., Florenzano, A., Pizzi, C., Marchesini, M., \& Zerboni, A. (2016). Climate change versus land management in the Po Plain (northern Italy) during the Bronze Age: New insights from the VP/VG sequence of the Terramara Santa Rosa di Poviglio. Quaternary Science Reviews, 136, 153-172.

Deininger, M., McDermott, F., Mudelsee, M., Werner, M., Frank, N., \& Mangini, A. (2017). Coherency of late Holocene European speleothem $\delta 180$ records linked to North Atlantic Ocean circulation. Climate Dynamics, 49(1-2), 595-618.

de Pablo, J. F. L., Gutiérrez-Roig, M., Gómez-Puche, M., McLaughlin, R., Silva, F., \& Lozano, S. (2019). Palaeodemographic modelling supports a population bottleneck during the Pleistocene-Holocene transition in Iberia. Nature Communications, 10(1), 1872. 
Di Gennaro, F. (2006). Individuazione, formulazione e percezione comune di caratteri significativi degli insediamenti protostorici. In A. Cardarelli, M. Pacciarelli, \& A. Vanzetti (Eds.), Studi di protostoria in onore di Renato Peroni (pp. 485-494). All'Insegna del Giglio.

Di Rita, F., Fletcher, W. J., Aranbarri, J., Margaritelli, G., Lirer, F., \& Magri, D. (2018). Holocene forest dynamics in central and western Mediterranean: Periodicity, spatio-temporal patterns and climate influence. Scientific Reports, 8(1), 8929.

Di Rita, F., \& Magri, D. (2009). Holocene drought, deforestation, and evergreen vegetation development in the central Mediterranean: A 5500-year record from Lago Alimini Piccolo, Apulia, southeast Italy. The Holocene, 19, 295-306.

Di Rita, F., \& Melis, R. T. (2013). The cultural landscape near the ancient city of Tharros (central West Sardinia): Vegetation changes and human impact. Journal of Archaeological Science, 40(12), 4271-4282.

Dolfini, A. (2019). From the Neolithic to the Bronze Age in central Italy: Settlement, burial, and social change at the dawn of metal production. Journal of Archaeological Research. https://doi. org/10.1007/s10814-019-09141-w

Drennan, R. D., Berrey, C. A., \& Peterson, C. E. (2015). Regional settlement demography in archaeology. Eliot Werner.

Drysdale, R., Zanchetta, G., Hellstrom, J., Maas, R., Fallick, A., Pickett, M., Cartwright, I., \& Piccini, L. (2006). Late Holocene drought responsible for the collapse of Old World civilizations is recorded in an Italian cave flowstone. Geology, 34(2), 101-104.

Edinborough, K., Porčić, M., Martindale, A., Brown, T. J., Supernant, K., \& Ames, K. M. (2017). Radiocarbon test for demographic events in written and oral history. Proceedings of the National Academy of Sciences, 114(47), 12436-12441.

Fasani, L. (2002). Età del Bronzo. In A. Aspes (Ed.), Preistoria veronese: Contributi e aggiornamenti (pp. 107-153). Museo Civico di Storia Naturale.

Fenu, P., Martini, F., \& Pitzalis, G. (1999). Gli scavi nella grotta Su Coloru (Sassari): Primi risultati e prospettive di ricerca. Rivista Di Scienze Preistoriche, 50, 165-187.

Ferrari, A., Pessina, A., \& Steffè, G. (2001). The Early Neolithic of central-eastern Emilia and of Romagna. Preistoria Alpina, 34, 253-262.

Fiorentino, G., Caldara, M., De Santis, V., D’Oronzo, C., Muntoni, I. M., Simone, O., Primavera, M., \& Radina, F. (2013). Climate changes and human-environment interactions in the Apulia region of southeastern Italy during the Neolithic period. The Holocene, 23(9), 1297-1316.

Finné, M., Woodbridge, J., Labuhn, I., \& Roberts, N. (2019). Holocene hydro-climatic variability in the Mediterranean: A synthetic multi-proxy reconstruction. The Holocene, 29(5), 847-863.

Foxhall, L. (2018). The central Mediterranean and the Aegean. In C. Haselgrove, K. Rebay-Salisbury, \& P. S. Wells (Eds.), The Oxford handbook of the European Iron Age. Oxford: Oxford University Press. https://doi.org/10.1093/oxfordhb/9780199696826.013.15

Fratianni, S., \& Acquaotta, F. (2017). The climate of Italy. In M. Soldati \& M. Marchetti (Eds.), Landscapes and landforms of Italy (pp. 29-38). Springer.

Freeman, J., Baggio, J. A., Robinson, E., Byers, D. A., Gayo, E., Finley, J. B., Meyer, J. A., Kelly, R. L., \& Anderies, J. M. (2018). Synchronization of energy consumption by human societies throughout the Holocene. Proceedings of the National Academy of Sciences, 115(40), 9962-9967.

Fredi, P., \& Lupia Palmieri, E. (2017). Morphological regions of Italy. In M. Soldati \& M. Marchetti (Eds.), Landscapes and landforms of Italy (pp. 39-74). Springer.

French, J. C. (2015). The demography of the Upper Palaeolithic hunter-gatherers of southwestern France: A multi-proxy approach using archaeological data. Journal of Anthropological Archaeology, 39, 193-209.

French, J. C., \& Collins, C. (2015). Upper Palaeolithic population histories of southwestern France: A comparison of the demographic signatures of 14C date distributions and archaeological site counts. Journal of Archaeological Science, 55, 122-134.

Frisia, S., Borsato, A., Mangini, A., Spötl, C., Madonia, G., \& Sauro, U. (2006). Holocene climate variability in Sicily from a discontinuous stalagmite record and the Mesolithic to Neolithic transition. Quaternary Research, 66(3), 388-400.

Frisia, S., Borsato, A., Preto, N., \& McDermott, F. (2003). Late Holocene annual growth in three Alpine stalagmites records the influence of solar activity and the North Atlantic Oscillation on winter climate. Earth and Planetary Science Letters, 216(3), 411-424. 
Fugazzola Delpino, M. A., D’Eugenio, G., \& Pessina, A. (1993). 'La Marmotta' (Anguillara Sabazia, Roma): Scavi 1979. Un abitato perilacustre di eta' neolitica. Bullettino Di Paletnologia Italiana, $48,181-342$.

Fugazzola Delpino, M. A., Manfredini, A., Martini, F., Radi, G., Sarti, L., \& Silvestrini, M. (2003). Insediamenti e strutture neolitiche ed eneolitiche dell'Italia centrale. In Atti della XXXV Riunione Scientifica dell'Istituto Italiano di Preistoria e Protostoria, vol. I (pp. 93-112). Florence: Istituto Italiano di Preistoria e Protostoria.

Fulminante, F. (2014). The urbanisation of Rome and Latium Vetus: From the Bronze Age to the Archaic era. Cambridge: Cambridge University Press.

Fulminante, F., Prignano, L., Morer, I., \& Lozano, S. (2017). Coordinated decisions and unbalanced power: How Latin cities shaped their terrestrial transportation network. Frontiers in Digital Humanities, 4, 4.

Gaastra, J. S., \& Vander Linden, M. (2018). Farming data: Testing climatic and palaeoenvironmental effect on Neolithic Adriatic stockbreeding and hunting through zooarchaeological meta-analysis. The Holocene, 28(7), 1181-1196.

Gennaro, F., \& Peroni, R. (1986). Aspetti regionali dello sviluppo dell'insediamento protostorico nell'Italia centro-meridionale alla luce dei dati archeologici e ambientali. Dialoghi Di Archeologia, 3, 193-200.

Giannitrapani, E. (2012). Aspetti culturali e dinamiche del popolamento di età preistorica della provincia di Enna. In Studi, ricerche, restauri per la tutela del patrimonio culturale Ennese. Quaderni del Patrimonio Culturale Ennese, 1, (pp. 145-181).

Giannitrapani, E. (2017). Paesaggi e dinamiche del popolamento di età preistorica nella Sicilia centrale. Mappa Data Book, 2, 43-64.

Giraudi, C., Magny, M., Zanchetta, G., \& Drysdale, R. N. (2011). The Holocene climatic evolution of Mediterranean Italy: A review of the continental geological data. The Holocene, 21(1), 105-115.

Goudeau, M. L. S., Grauel, A. L., Tessarolo, C., Leider, A., Chen, L., Bernasconi, S. M., Versteegh, G. J., Zonneveld, K. A., Boer, W., Alonso-Hernandez, C. M., \& De Lange, G. J. (2014). The GlacialInterglacial transition and Holocene environmental changes in sediments from the Gulf of Taranto, central Mediterranean. Marine Geology, 348, 88-102.

Grifoni Cremonesi, R. (1992). Il Neolitico nell'Italia centrale e in Sardinia. In A. Guidi \& M. Piperno (Eds.), Italia Preistorica (pp. 306-333). Laterza.

Hinz, M., Furholt, M., Müller, J., Raetzel-Fabian, D., Rinne, C., Sjögren, K. G., \& Wotzka, H. P. (2012). RADON-Radiocarbon dates online 2012. Central European database of 14C dates for the Neolithic and the Early Bronze Age. Journal of Neolithic Archaeology, 14, 1-4.

Iacono, F. (2018). The archaeology of Late Bronze Age interaction and mobility at the Gates of Europe. Bloomsbury Academic.

Ippolito, F. (2016). Late Eneolithic and Early Bronze Age funerary evidence from the Sant'Angelo IV Cave (northeastern Calabria, Italy). Palaeohistoria, 58, 111-116.

Isola, I., Zanchetta, G., Drysdale, R., Regattieri, E., Bini, M., Bajo, P., Hellstrom, J. C., Baneschi, I., Lionello, P., Woodhead, J., \& Greig, A. (2019). The 4.2 ka event in the central Mediterranean: New data from a Corchia speleothem (Apuan Alps, central Italy). Climate of the Past, 15, 135-151.

ISTAT (2018). Conti economici territoriali. https://www.istat.it/it/archivio/224949. Accessed 25 June 2020.

Joannin, S., Brugiapaglia, E., de Beaulieu, J. L., Bernardo, L., Magny, M., Peyron, O., Goring, S., \& Vannière, B. (2012). Pollen-based reconstruction of Holocene vegetation and climate in southern Italy: The case of Lago di Trifoglietti. Climate of the Past, 8, 1973-1996.

Kaniewski, D., Guiot, J., \& Van Campo, E. (2015). Drought and societal collapse 3200 years ago in the eastern Mediterranean: A review. Wiley Interdisciplinary Reviews: Climate Change, 6(4), 369-382.

Kaniewski, D., Marriner, N., Bretschneider, J., Jans, G., Morhange, C., Cheddadi, R., Otto, T., Luce, F., \& Van Campo, E. (2019). 300-year drought frames Late Bronze Age to Early Iron Age transition in the Near East: New palaeoecological data from Cyprus and Syria. Regional Environmental Change, 19(8), 2287-2297.

Krauss, R., Elenski, N., Weninger, B., Lee, C., Çakırlar, C., \& Zidarov, P. (2014). Beginnings of the Neolithic in southeast Europe: The Early Neolithic sequence and absolute dates from DžuljunicaSmărdeš (Bulgaria). Documenta Praehistorica, 41, 51-77.

Langgut, D., Finkelstein, I., \& Litt, T. (2013). Climate and the Late Bronze collapse: New evidence from the southern Levant. Tel Aviv, 40(2), 149-175. 
Lanzinger, M. (1996). Sistemi di insediamento mesolitico come adattamento agli ambienti montani alpini. In S. K. Koslowski \& C. Tozzi (Eds.), Proceedings of the XIII international congress of prehistoric and protohistoric sciences 1: The Mesolithic (pp. 125-140). Forlí: UISPP.

Leng, M. J., \& Marshall, J. D. (2004). Palaeoclimate interpretation of stable isotope data from lake sediment archives. Quaternary Science Reviews, 23(7-8), 811-831.

Leppard, T. P. (2014). Mobility and migration in the Early Neolithic of the Mediterranean: Questions of motivation and mechanism. World Archaeology, 46(4), 484-501.

Livadie, C. A., Pearce, M., Delle Donne, M., \& Pizzano, N. (2019). The effects of the Avellino Pumice eruption on the population of the Early Bronze Age Campanian plain (Southern Italy). Quaternary International, 499, 205-220.

Lo Porto, F. (1989). L'insediamento neolitico di Serra d'Alto nel Materano. Giorgio Bretschneider.

Lo Schiavo, F. (2013). The Bronze Age in Sardinia. In A. Harding \& H. Fokkens (Eds.), The Oxford handbook of the European Bronze Age (pp. 669-691). Oxford University Press.

Lo Vetro, D., \& Martini, F. (2016). Mesolithic in central-southern Italy: Overview of lithic productions. Quaternary International, 423, 279-302.

Lowe, J. J., Branch, N., \& Watson, C. (1994). The chronology of human disturbance of the vegetation of the northern Apennines during the Holocene. In P. Biagi \& J. Nandris (Eds.), Highland zone exploitation in southern Europe. Monografie di Natura Bresciana 20 (pp. 169-187). Museo Civico di Scienze Naturali di Brescia.

Lugliè, C. (2009). Il Neolitico Antico. In C. Lugliè \& R. Cicilloni (Eds.), Atti della XLIV Riunione Scientifica dell'IIPP: La preistoria e la protostoria della Sardegna (vol.1, pp. 37-47). Istituto Italiano di Preistoria e Protostoria

Maggi, R. (1983). Il Neolitico. In R. Maggi (Ed.), Preistoria nella Liguria Orientale (pp. 45-58). Siri.

Maggi, R. (1997). The radiocarbon chronology. In R. Maggi (Ed.), Arene Candide: A functional and environmental assessment of the Holocene sequence (pp. 31-52). Il Calamo.

Magny, M., Combourieu-Nebout, N., de Beaulieu, J. L., Bout-Roumazeilles, V., Colombaroli, D., Desprat, S., Francke, A., Joannin, S., Ortu, E., \& Peyron, O. (2013). North-south palaeohydrological contrasts in the central Mediterranean during the Holocene: Tentative synthesis and working hypotheses. Climate of the Past, 9, 2043-2071.

Magny, M., de Beaulieu, J. L., Drescher-Schneider, R., Vannière, B., Walter-Simonnet, A. V., Miras, Y., Millet, L., Bossuet, G., Peyron, O., Brugiapaglia, E., \& Leroux, A. (2007b). Holocene climate changes in the central Mediterranean as recorded by lake-level fluctuations at Lake Accesa (Tuscany, Italy). Quaternary Science Reviews, 26, 1736-1758.

Magny, M., Vannière, B., Calo, C., Millet, L., Leroux, A., Peyron, O., Zanchetta, G., La Mantia, T., \& Tinner, W. (2011). Holocene hydrological changes in south-western Mediterranean as recorded by lake-level fluctuations at Lago Preola, a coastal lake in southern Sicily Italy. Quaternary Science Reviews, 30(19-20), 2459-2475.

Magny, M., Vannière, B., de Beaulieu, J. L., Bégeot, C., Heiri, O., Millet, L., Peyron, O., \& WalterSimonnet, A. V. (2007a). Early-Holocene climatic oscillations recorded by lake-level fluctuations in west-central Europe and in central Italy. Quaternary Science Reviews, 26(15-16), 1951-1964.

Magny, M., Vannière, B., Zanchetta, G., Fouache, E., Touchais, G., Petrika, L., Coussot, C., WalterSimonnet, A. V., \& Arnaud, F. (2009). Possible complexity of the climatic event around 4300$3800 \mathrm{cal}$. BP in the central and western Mediterranean. The Holocene, 19, 823-833.

Magri, D., Agrillo, E., Di Rita, F., Furlanetto, G., Pini, R., Ravazzi, C., \& Spada, F. (2015). Holocene dynamics of tree taxa populations in Italy. Review of Palaeobotany and Palynology, 218, 267-284.

Magri, D., \& Sadori, L. (1999). Late Pleistocene and Holocene pollen stratigraphy at Lago di Vico, central Italy. Vegetation History and Archaeobotany, 8(4), 247-260.

Malone, C. (2003). The Italian Neolithic: A synthesis of research. Journal of World Prehistory, 17(3), 235-312.

Malone, C., \& Stoddart, S. (1994). Territory, time and state: The archaeological development of the Gubbio Basin. Cambridge University Press.

Malone, C., \& Stoddart, S. (2000). A house in the Sicilian hills. Antiquity, 74, 471-472.

Manfredini, A., Fugazzola Delpino, M. A., Sarti, L., Silvestrini, M., \& Martini, F. (2009). Adriatico e Tirreno a confronto: Analisi dell'occupazione territoriale tra il Neolitico finale e l'età del Rame in alcune aree campione dell'Italia centrale. Rivista Di Scienze Preistoriche, 59, 115-179.

Manfredini, A., Sarti, L., and Silvestrini, M. (2005). Il Neolitico delle Marche. In Atti della Riunione Scientifica dell'Istituto Italiano di Preistoria e Protostoria (vol. I, pp.197-208). Istituto Italiano di Preistoria e Protostoria. 
Manning, K., Colledge, S., Crema, E., Shennan, S. \& Timpson, A. (2016). The cultural evolution of neolithic Europe. EUROEVOL dataset 1: Sites, phases and radiocarbon data. Journal of Open Archaeology Data, 5, p.e2.

Mannino, M., Thomas, K. D., Leng, M. J., Piperno, M., Tusa, S., \& Tagliacozzo, A. (2007). Marine resources in the Mesolithic and Neolithic at the Grotta dell'Uzzo (Sicily): Evidence from isotope analyses of marine shells. Archaeometry, 49(1), 117-133.

Mannino, M. A., Catalano, G., Talamo, S., Mannino, G., Di Salvo, R., Schimmenti, V., Lalueza-Fox, C., Messina, A., Petruso, D., Caramelli, D., Richards, M. P., \& Sineo, L. (2012). Origin and diet of the prehistoric hunter-gatherers on the Mediterranean Island of Favignana (Egadi Islands, Sicily). PLoS ONE, 7(11), e49802. https://doi.org/10.1371/journal.pone.0049802

Marchetti, M., Soldati, M., \& Vandelli, V. (2017). The great diversity of Italian landscapes and landforms: Their origin and human imprint. In M. Soldati \& M. Marchetti (Eds.), Landscapes and landforms of Italy (pp. 7-20). Springer.

Marino, D., 1998. Aspetti dell'insediamento nella Calabria centro-orientale tra età del bronzo recente e prima eta' del Ferro. In N. Negroni Catacchio (Ed.), Atti del III Incontro di Studi sulla Preistoria e Protostoria in Etruria (Manciano-Farnese 12-14.5.1995) (pp. 145-158). Florence: Octavo.

Marino, S. (2020). Across the Strait. New evidence on cultural interconnections and exchanges between Calabria and Sicily during the early Bronze Age. Journal of Archaeological Science: Reports, 29, 164.

Martini F., Sarti L., Pitzalis G., \& Fenu P. (2007). La grotte de Su Coloru en Sardaigne dans le cadre culturel de la haute Mer Tyrrhénienne au Mésolithique et au Néolithique ancien. In A. D’Anna, J. Cesari, L. Ogel, \& J. Vaquer (Eds.), Corse et Sardaigne préhistoriques : Relations et échanges dans le contexte méditerranéen. Actes du $128^{e}$ Congrès national des sociétés historiques et scientifiques, Section de pré- et protohistoire, Bastia, avril 2003 (pp. 49-58). Paris: Éd. du Comité des travaux historiques et scientifiques.

Mercuri, A. M., Accorsi, C. A., \& Mazzanti, M. B. (2002). The long history of cannabis and its cultivation by the Romans in central Italy, shown by pollen records from Lago Albano and Lago di Nemi. Vegetation History and Archaeobotany, 11(4), 263-276.

Mercuri, A. M., Mazzanti, M. B., Florenzano, A., Montecchi, M. C., \& Rattighieri, E. (2013). Olea, Juglans and Castanea: The OJC group as pollen evidence of the development of human-induced environments in the Italian peninsula. Quaternary International, 303, 24-42.

Mercuri, A. M., Sadori, L., \& Uzquiano Ollero, P. (2011). Mediterranean and north-African cultural adaptations to mid-Holocene environmental and climatic changes. The Holocene, 21(1), 189-206.

McLaughlin, T. R. (2019). On applications of space-time modelling with open-source 14C age calibration. Journal of Archaeological Method and Theory, 26(2), 479-501.

Minniti, C. (2012). Ambiente, sussistenza e articolazione sociale nell'Italia centrale tra Bronzo medio e Primo Ferro. BAR International series. Archaeopress.

Morellón, M., Anselmetti, F. S., Ariztegui, D., Brushulli, B., Sinopoli, G., Wagner, B., Sadori, L., Gilli, A., \& Pambuku, A. (2016). Human-climate interactions in the central Mediterranean region during the last millennia: The laminated record of Lake Butrint (Albania). Quaternary Science Reviews, $136,134-152$.

Moreno, A., Svensson, A., Brooks, S. J., Connor, S., Engels, S., Fletcher, W., Genty, D., Heiri, O., Labuhn, I., Perşoiu, A., \& Peyron, O. (2014). A compilation of Western European terrestrial records 60-8 ka BP: Towards an understanding of latitudinal climatic gradients. Quaternary Science Reviews, 106, 167-185.

Moser, D., Di Pasquale, G., Scarciglia, F., \& Nelle, O. (2017). Holocene mountain forest changes in central Mediterranean: Soil charcoal data from the Sila Massif (Calabria, southern Italy). Quaternary International, 457, 113-130.

Natali, E., \& Forgia, V. (2018). The beginning of the Neolithic in southern Italy and Sicily. Quaternary International, 470, 253-269.

Nicolis, F. (2013). Northern Italy. In A. Harding \& H. Fokkens (Eds.), The Oxford handbook of the European Bronze Age (pp. 693-705). Oxford University Press.

Nielsen, S. V., Persson, P., \& Solheim, S. (2019). De-Neolithisation in southern Norway inferred from statistical modelling of radiocarbon dates. Journal of Anthropological Archaeology, 53, 82-91.

Noti, R., van Leeuwen, J. F., Colombaroli, D., Vescovi, E., Pasta, S., La Mantia, T., \& Tinner, W. (2009). Mid-and Late-Holocene vegetation and fire history at Biviere di Gela, a coastal lake in southern Sicily Italy. Vegetation History and Archaeobotany, 18(5), 371-387. 
Pacciarelli, M. (2001). Dal villaggio alla città: La svolta protourbana del 1000 aC nell'Italia tirrenica. All'insegna del Giglio.

Pacciarelli, M., Scarano, T., \& Crispino, A. (2015). The transition between the Copper and Bronze Ages in southern Italy and Sicily. In H. Meller, H. W. Arz, R. Jung, \& R. Risch (Eds.), 2200 BC: A climatic breakdown as a cause for the collapse of the Old World (pp. 253-282). Landesamt für Denkmalpflege und Archäologie Sachsen-Anhalt, Landesmuseum für Vorgeschichte.

Palmisano, A., Bevan, A., \& Shennan, S. (2017). Comparing archaeological proxies for long-term population patterns: An example from central Italy. Journal of Archaeological Science, 87, 59-72.

Palmisano, A., Bevan, A., \& Shennan, S. (2018). Regional demographic trends and settlement patterns in central italy: Archaeological sites and radiocarbon dates. Journal of Open Archaeology Data, 6(1).

Palmisano, A., Woodbridge, J., Roberts, N., Bevan, A., Fyfe, R., Shennan, S., Cheddadi, R., Greenberg, R., Kaniewski, D., Langgut, D., Leroy, S. A., Litt, T., \& Miebach, A. (2019). Holocene landscape dynamics and long-term population trends in the Levant. The Holocene, 29(5), 708-727.

Parkinson, E. W., McLaughlin, T. R., Esposito, C., Stoddart, S., \& Malone, C. (2021). Radiocarbon dated trends and central Mediterranean prehistory. Journal of Word Prehistory. https://doi.org/10.1007/ s10963-021-09158-4

Pearce, M. (2013). Rethinking the north Italian Early Neolithic. Accordia Specialist Studies on Italy 17. Accordia Research Centre.

Peroni, R. (1988). Comunità e insediamento in Italia tra età del bronzo e prima età del ferro. In A. Momigliano \& A. Schiavone (Eds.), Storia di Roma, I: Roma in Italia (pp. 7-37). Einaudi.

Peroni, R. (1996). L'Italia alle soglie della storia. Laterza.

Peroni, R. (2000). Formazione e sviluppo dei centri protourbani medio-tirrenici. In A. Carandini \& R. Cappeili (Eds.), Roma, Romolo, Remo e la fondazione della città (pp. 26-30). Electa.

Pessina, A., \& Rottoli, M. (1996). New evidence on the earliest farming cultures in northern Italy: Archaeological and palaeobotanical data. Porocilo o Raziskovanju Paleoliticka, Neolitika in Eneolitika $v$ Sloveniji, 23, 7-103.

Pessina, A., \& Tinè, V. (2008). Archeologia del neolitico. Carocci.

Pilaar Birch, S. E., \& Vander Linden, M. (2018). A long hard road ... Reviewing the evidence for environmental change and population history in the eastern Adriatic and western Balkans during the Late Pleistocene and Early Holocene. Quaternary International, 465, 177-191.

Porčić, M., Blagojević, T., \& Stefanović, S. (2016). Demography of the Early Neolithic population in central Balkans: Population dynamics reconstruction using summed radiocarbon probability distributions. PLOS ONE, 11(8), e0160832.

Prignano, L., Morer, I., Fulminante, F., \& Lozano, S. (2019). Modelling terrestrial route networks to understand inter-polity interactions (southern Etruria, 950-500 BC). Journal of Archaeological Science, 105, 46-58.

Radi, G., \& Pannocchia, C. P. (2018). The beginning of the Neolithic era in central Italy. Quaternary International, 470, 270-284.

Radina, F., Pofi, G., Vitale, V., \& Pizzarelli, A. (2017). L'insediamento nell'Alta Murgia tra mediaetà del Bronzo e prima età del Ferro. In F. Redina (Ed.), Preistoria e Protostoria della Puglia Studi Di Preistoria e Protostoria 4 (pp. 481-488). Istituto Italiano di Preistoria e Protostoria.

Ramsey, C. (2017). Methods for summarizing radiocarbon datasets. Radiocarbon, 59(6), 1809-1833.

Redhouse, D. I., \& Stoddart, S. (2011). Mapping Etruscan state formation. In N. Terrenato \& D. C. Haggis (Eds.), State formation in Italy and Greece: Questioning the neoevolutionist paradigm (pp. 162-178). Oxbow.

Reimer, P. J., Bard, E., Bayliss, A., Beck, J. W., Blackwell, P. G., Ramsey, C. B., Buck, C. E., Cheng, H., Edwards, R. L., Friedrich, M., \& Grootes, P. M. (2013). IntCal13 and Marine13 radiocarbon age calibration curves 0-50,000 years cal BP. Radiocarbon, 55(4), 1869-1887.

Rick, J. W. (1987). Dates as data: An examination of the Peruvian radiocarbon record. American Anitquity, 52, 55-73.

Riede, F. (2009). Climate and demography in early prehistory: Using calibrated 14C dates as population proxies. Human Biology, 81(3), 309-337.

Riris, P. (2018). Dates as data revisited: A statistical examination of the Peruvian preceramic radiocarbon record. Journal of Archaeological Science, 97, 67-76.

Riris, P., \& Arroyo-Kalin, M. (2019). Widespread population decline in South America correlates with mid-Holocene climate change. Scientific Reports, 9(1), 6850.

Riva, C. (2009). The urbanisation of Etruria: Funerary practices and social change, 700-600 BC. Cambridge University Press. 
Robb, J. (2007). The early Mediterranean village: Agency, material culture, and social change in Neolithic Italy. Cambridge University Press.

Robb, J., \& Miracle, P. (2007). Beyond 'migration' versus 'acculturation': New models for the spread of agriculture. In A. Whittle \& V. Cummings (Eds.), Going over: The Mesolithic-Neolithic transition in Western Europe (pp. 97-113). British Academy.

Robb, J., \& Van Hove, D. (2003). Gardening, foraging and herding: Neolithic land use and social territories in southern Italy. Antiquity, 77(296), 241-254.

Roberts, N., Brayshaw, D., Kuzucuoğlu, C., Perez, R., \& Sadori, L. (2011). The mid-Holocene climatic transition in the Mediterranean: Causes and consequences. The Holocene, 21(1), 3-13.

Roberts, N., Jones, M. D., Benkaddour, A., Eastwood, W. J., Filippi, M. L., Frogley, M. R., Lamb, H. F., Leng, M. J., Reed, J. M., Stein, M., \& Stevens, L. (2008). Stable isotope records of Late Quaternary climate and hydrology from Mediterranean lakes: The ISOMED synthesis. Quaternary Science Reviews, 27(25-26), 2426-2441.

Roberts, N., Meadows, M. E., \& Dodson, J. R. (2001). The history of Mediterranean-type environments: Climate, culture and landscape. The Holocene, 11(6), 631-634.

Roberts, N., Woodbridge, J., Bevan, A., Palmisano, A., Shennan, S., \& Asouti, E. (2018). Human responses and non-responses to climatic variations during the last glacial-interglacial transition in the eastern Mediterranean. Quaternary Science Reviews, 184, 47-67.

Roberts, C. N., Woodbridge-Fisher, J., Palmisano, A., Bevan, A., Fyfe, R. M., \& Shennan, S. (2019). Mediterranean landscape change during the Holocene: Synthesis, comparison and regional trends in population, land cover and climate. The Holocene, 29(5), 923-937.

Robinson, E., Zahid, H. J., Codding, B. F., Haas, R., \& Kelly, R. L. (2019). Spatiotemporal dynamics of prehistoric human population growth: Radiocarbon 'dates as data' and population ecology models. Journal of Archaeological Science, 101, 63-71.

Saccoccio, F., Marzocchella, A., \& Vanzetti, A. (2013). The field system of Gricignano d'Aversa (southern Italy) and the agrarian impact in the Piana Campana, ca. 3900 cal BP. Quaternary International, 303, 82-92.

Sadori, L., \& Giardini, M. (2007). Charcoal analysis, a method to study vegetation and climate of the Holocene: The case of Lago di Pergusa, Sicily (Italy). Geobios, 40, 173-180.

Sadori, L., Giraudi, C., Petitti, P., \& Ramrath, A. (2004). Human impact at Lago di Mezzano (central Italy) during the Bronze Age: A multidisciplinary approach. Quaternary International, 113, 5-17.

Sadori, L., \& Narcisi, B. (2001). The Postglacial record of environmental history from Lago di Pergusa Sicily. The Holocene, 11(6), 655-671.

Sadori, L., Zanchetta, G., \& Giardini, M. (2008). Last Glacial to Holocene palaeoenvironmental evolution at Lago di Pergusa (Sicily, southern Italy) as inferred by pollen, microcharcoal, and stable isotopes. Quaternary International, 181(1), 4-14.

Salque, M., Radi, G., Tagliacozzo, A., Uria, B. P., Wolfram, S., Hohle, I., Stäuble, H., Hofmann, D., Whittle, A., Pechtl, J., Schade-Lindig, S., Eisenhauer, U., \& Evershed, R. P. (2012). New insights into the Early Neolithic economy and management of animals in Southern and Central Europe revealed using lipid residue analyses of pottery vessels. Anthropozoologica, 47(2), 45-62.

Scholz, D., Frisia, S., Borsato, A., Spötl, C., Fohlmeister, J., Mudelsee, M., Miorandi, R., \& Mangini, A. (2012). Holocene climate variability in north-eastern Italy: Potential influence of the NAO and solar activity recorded by speleothem data. Climate of the Past, 8(4), 1367-1383.

Sevink, J., Bakels, C. C., Attema, P. A., Di Vito, M. A., \& Arienzo, I. (2019). Holocene vegetation record of upland northern Calabria, Italy: Environmental change and human impact. The Holocene, 29(4), 633-647.

Shennan, S. (2000). Population, culture history, and the dynamics of culture change. Current Anthropology, 41, 811-835.

Shennan, S. (2001). Demography and cultural innovation: A model and its implications for the emergence of modern human culture. Cambridge Archaeological Journal, 11(1), 5-16.

Shennan, S. (2018). The first farmers of Europe: An evolutionary perspective. Cambridge University Press.

Shennan, S., \& Edinborough, K. (2007). Prehistoric population history: From the Late Glacial to the Late Neolithic in central and northern Europe. Journal of Archaeological Science, 34, 1339-1345.

Shennan, S., Downey, S. S., Timpson, A., Edinborough, K., Colledge, S., Kerig, T., Manning, K., \& Thomas, M. G. (2013). Regional population collapse followed initial agriculture booms in midHolocene Europe. Nature Communications, 4, 2486. 
Siani, G., Magny, M., Paterne, M., Debret, M., \& Fontugne, M. (2013). Paleohydrology reconstruction and Holocene climate variability in the south Adriatic Sea. Climate of the past, 9, 499-515.

Silva, F., \& Vander Linden, M. (2017). Amplitude of travelling front as inferred from 14C predicts levels of genetic admixture among European early farmers. Scientific Reports, 7(1), 11985.

Skeates, R. (1994). Towards an absolute chronology for the Neolithic of central Italy. In R. Skeates \& R. Whitehouse (Eds.), Radiocarbon dating and Italian prehistory. Accordia Specialist Studies on Italy 3 (pp. 45-60). London: Archaeological Monographs of the British School at Rome.

Skeates, R. (2002). The Neolithic enclosures of the Tavoliere, south-east Italy. In G. Varndell \& P. Topping (Eds.), Enclosures in Neolithic Europe: Essays on causewayed and non-causewayed sites (pp. 51-58). Oxbow.

Skeates, R. (2003). Radiocarbon dating and interpretations of the Mesolithic-Neolithic transition in Italy. In A. J. Ammerman \& P. Biagi (Eds.), The widening harvest. The Neolithic transition in Europe: Looking back, looking forward (pp. 157-187). Archaeological Institute of America.

Sommella, P. (2009). Esperienze documentali sul territorio dagli anni '80 ad oggi: Alcune considerazioni. Archeologia e Calcolatori, 20, 47-59.

Spiteri, C., Muntoni, I. M., \& Craig, O. E. (2017). Dietary practices at the onset of the Neolithic in the western Mediterranean revealed using a combined biomarker and isotopic approach. In O. GarcíaPuchol \& D. C. Salazar-García (Eds.), Times of Neolithic transition along the western Mediterranean. Fundamental Issues in Archaeology (pp. 253-279). Springer.

Starnini, E., Biagi, P., \& Mazzucco, N. (2018). The beginning of the Neolithic in the Po plain (northern Italy): Problems and perspectives. Quaternary International, 470, 301-317.

Stoddart, S. (2016). Power and place in Etruria. In M. Fernàndez-Götz \& D. Krausse (Eds.), Eurasia at the dawn of history: Urbanization and social change (pp. 304-318). Cambridge University Press.

Stoddart, S., Palmisano, A., Redhouse, D., Barker, G., di Paola, G., Rasmussen, T., Samuels, T., Terrenato, N., \& Witcher, R. (2020). Patterns of Etruscan urbanism. Frontiers in Digital Humanities, 7, 1. https://doi.org/10.3389/fdigh.2020.00001

Stoddart, S., Woodbridge, J., Palmisano, A., Mercuri, A. M., Mensing, S. A., Colombaroli, D., Sadori, L., Magri, L., Di Rita, F., Giardini, M., Mariotti, M., Montanari, C., Bellini, C., Florenzano, A., Torri, P., Bevan, A., Shennan, S., Fyfe, R., \& Roberts, N. (2019). Tyrrhenian central Italy: Holocene population and landscape ecology. The Holocene, 29(5), 761-775.

Surovell, T. A., Byrd Finley, J., Smith, G. M., Brantingham, P. J., \& Kelly, R. (2009). Correcting temporal frequency distributions for taphonomic bias. Journal of Archaeological Science, 36, 1715-1724.

Tallavaara, M., Pesonen, P., \& Oinonen, M. (2010). Prehistoric population history in eastern Fennoscandia. Journal of Archaeological Science, 37(2), 251-260.

Tanda, G. (1995). I siti del neolitico antico e l'ambiente: Strategie di sussistenza. Interreg Préhistoire Corse-Sardaigne, 2, 17-29.

Teržan, B., \& De Marinis, R. (2018). The northern Adriatic. In C. Haselgrove, K. Rebay-Salisbury, \& P. S. Wells (Eds.), The Oxford handbook of the European Iron Age. Oxford University Press . https:// doi.org/10.1093/oxfordhb/9780199696826.013.32

Timpson, A., Colledge, S., Crema, E., Edinborough, K., Kerig, T., Manning, K., Thomas, M. G., \& Shennan, S. (2014). Reconstructing regional population fluctuations in the European Neolithic using radiocarbon dates: A new case study using an improved method. Journal of Archaeological Science, 52, 549-557.

Tinè, S. (1983). Passo di Corvo e la civiltà neolitica del Tavoliere. Sagep.

Tinner, W., van Leeuwen, J. F., Colombaroli, D., Vescovi, E., van der Knaap, W. O., Henne, P. D., Pasta, S., D’Angelo, S., \& La Mantia, T. (2009). Holocene environmental and climatic changes at Gorgo Basso, a coastal lake in southern Sicily Italy. Quaternary Science Reviews, 28(15-16), 1498-1510.

Tinner, W., Vescovi, E., van Leeuwen, J. F., Colombaroli, D., Henne, P. D., Kaltenrieder, P., MoralesMolino, C., Beffa, G., Gnaegi, B., van der Knaap, W. O., \& La Mantia, T. (2016). Holocene vegetation and fire history of the mountains of northern Sicily (Italy). Vegetation Hstory and Archaeobotany, 25(5), 499-519.

Torfing, T. (2015a). Layers of assumptions: A reply to Timpson, Manning, and Shennan. Journal of Archaeological Science, 63, 203-205.

Torfing, T. (2015b). Neolithic population and summed probability distribution of 14C dates. Journal of Archaeological Science, 63, 193-198.

Turchin, P. (2001). Does population ecology have general laws? Oikos, 94(1), 17-26.

Turchin, P., Currie, T., Whitehouse, H., Francois, P., Feeney, K., Mullins, D., Hoyer, D., Collins, C., Grohmann, S., Savage, P., Mendel-Gleason, G., Turner, E., Dupeyron, A., Cioni, E., Reddish, J., 
Levine, J., Jordan, G., Brandl, E., Williams, A., ... Spencer, C. (2018). Quantitative historical analyses uncover a single dimension of complexity that structures global variation in human social organization. Proceedings of the National Academy of Sciences, 115(2), E144-E151.

Tusa, S. (1999). La Sicilia nella preistoria. Sellerio Editore.

Valbruzzi, F. (2009). Il sistema insediativo antico e i beni archeologici. Quaderni Dell'istituto Nazionale Di Urbanistica, 53, 86-92.

Vallino, F. O. (1984). Attività agropastorali, basi alimentari ed ipotesi demografiche. In R. Peroni (Ed.), Nuove ricerche sulla protostoria della Sibaritide. Paleani.

Vander Linden, M. (2011). In constant motion? Recent advances in mathematical modelling and radiocarbon chronology of the neolithisation of Europe. In A. Hadjikoumis, E. Robinson, \& S. Viner (Eds.), Dynamics of Neolithisation: Studies in honour of Andrew Sherratt (pp. 41-61). Oxbow.

Vanzetti, A. (2002). Some current approaches to protohistoric centralization and urbanization in Italy. In P. Attema, G. J. Burgers, E. van Joolen, M. van Leusen, \& B. Mater (Eds.), New developments in Italian landscape archaeology: Theory and methodology of field survey, land evaluation and landscape perception, pottery production and distribution. BAR International Series 1091 (pp. 36-51). Archaeopress.

Vanzetti, A., Castangia, G., Depalmas, A., Ialongo, N., \& Leonelli, V. (2013). Complessi fortificati della Sardegna e delle isole del Mediterraneo occidentale nella protostoria. Scienze Dell'antichità, $19(2 / 3), 83-123$.

Villari, P. (1995). Le faune della tarda preistoria nella Sicilia orientale. Ente Fauna Siciliana.

Von Eles Masi, P., \& Steffè, G. (1987). Primi risultati delle richerche nell'insediamento neolitico di Lugo di Romagna (Ravenna). In Atti della XXVI Riunione Scientifica dell'Istituto della Preistoria e Protostoria (pp. 595-602). Istituto Italiano di Preistoria e Protostoria.

Voza, G. (1999). Nel segno dell'antico. Palermo: Arnaldo Lombardi.

Wassenburg, J. A., Dietrich, S., Fietzke, J., Fohlmeister, J., Jochum, K. P., Scholz, D., Richter, D. K., Sabaoui, A., Spötl, C., Lohmann, G., \& Andreae, M. O. (2016). Reorganization of the North Atlantic Oscillation during Early Holocene deglaciation. Nature Geoscience, 9(8), 602-605.

Weiberg, E., Bevan, A., Kouli, K., Katsianis, M., Woodbridge, J., Bonnier, A., Engel, M., Finné, M., Fyfe, R., Maniatis, Y., \& Palmisano, A. (2019). Long-term trends of land use and demography in Greece: A comparative study. The Holocene, 29(5), 742-760.

Weninger, B. (2018). CalPal archaeological 14C-database. https://www.academia.edu/36766067/CalPal_Archaeological_14C-Database_Europe.xlsx_June_2018

Weninger, B., Alram-Stern, E., Bauer, E., Clare, L., Danzeglocke, U., Jöris, O., Kubatzki, C., Rollefson, G., Todorova, H., \& van Andel, T. (2006). Climate forcing due to the 8200 cal yr BP event observed at Early Neolithic sites in the eastern Mediterranean. Quaternary Research, 66(3), $401-420$.

Weninger, B., Clare, L., Jöris, O., Jung, R., \& Edinborough, K. (2015). Quantum theory of radiocarbon calibration. World Archaeology, 47(4), 543-566.

Weninger, B., Clare, L., Rohling, E., Bar-Yosef, O., Böhner, U., Budja, M., Bundschuh, M., Feurdean, A., Gebe, H. G., Jöris, O., \& Linstädter, J. (2009). The impact of rapid climate change on prehistoric societies during the Holocene in the eastern Mediterranean. Documenta Praehistorica, 36, 7-59.

Whitehouse, R. (2014). The chronology of the Neolithic ditched settlements of the Tavoliere and the Ofanto valley. Accordia Research Papers, 13, 57-77.

Whittle, A., \& Cummings, V. (Eds.). (2007). Going over: The Mesolithic-Neolithic transition in Western Europe. British Academy.

Wigand, P., \& McCallum, M. (2017). The varying impact of land use and climate in Holocene landscape dynamics in the Mezzogiorno. Journal of Mediterranean Studies, 3(2), 121-150.

Williams, A. N. (2012). The use of summed radiocarbon probability distributions in archaeology: A review of methods. Journal of Archaeological Science, 39(3), 578-589.

Williams, A. N., Ulm, S., Goodwin, I., \& Smith, M. (2010). Hunter-gatherer response to Late Holocene climatic variability in northern and central Australia. Journal of Quaternary Science, 25(6), 831-838.

Zanchetta, G., Borghini, A., Fallick, A. E., Bonadonna, F. P., \& Leone, G. (2007b). Late Quaternary palaeohydrology of Lake Pergusa (Sicily, southern Italy) as inferred by stable isotopes of lacustrine carbonates. Journal of Paleolimnology, 38(2), 227-239.

Zanchetta, G., Drysdale, R. N., Hellstrom, J. C., Fallick, A. E., Isola, I., Gagan, M. K., \& Pareschi, M. T. (2007a). Enhanced rainfall in the western Mediterranean during deposition of sapropel S1: Stalagmite evidence from Corchia cave (central Italy). Quaternary Science Reviews, 26(3-4), 279-286. 
Zanchetta, G., Regattieri, E., Isola, I., Drysdale, R. N., Bini, M., Baneschi, I., \& Hellstrom, J. C. (2016). The so-called ' 4.2 event' in the central Mediterranean and its climatic teleconnections. Alpine and Mediterranean Quaternary, 29(1), 5-17.

Zanchetta, G., Van Welden, A., Baneschi, I., Drysdale, R., Sadori, L., Roberts, N., Giardini, M., Beck, C., Pascucci, V., \& Sulpizio, R. (2012). Multiproxy record for the last 4500 years from Lake Shkodra (Albania/Montenegro). Journal of Quaternary Science, 27(8), 780-789.

Zielhofer, C., Köhler, A., Mischke, S., Benkaddour, A., Mikdad, A., \& Fletcher, W. J. (2019). Western Mediterranean hydro-climatic consequences of Holocene ice-rafted debris (Bond) events. Climate of the Past, 15, 463-475.

Publisher's Note Springer Nature remains neutral with regard to jurisdictional claims in published maps and institutional affiliations.

\section{Authors and Affiliations}

\section{Alessio Palmisano ${ }^{1}$ (D) Andrew Bevan ${ }^{2}$ (D) $\cdot$ Alexander Kabelindde ${ }^{2}$. Neil Roberts ${ }^{3,4}$. Stephen Shennan ${ }^{2}$}

$\triangle$ Alessio Palmisano

A.Palmisano@1mu.de

1 Department of Ancient History, Ludwig Maximilian University of Munich, Munich, DE, Germany

2 Institute of Archaeology, University College London, London, UK

3 School of Geography, Earth and Environmental Sciences, University of Plymouth, Plymouth, UK

4 School of Archaeology, University of Oxford, Oxford, UK 